\title{
THE INFLUENCE OF ATMOSPHERIC CIRCULATION AT DIFFERENT SPATIAL SCALES ON WINTER DROUGHT VARIABILITY THROUGH A SEMI-ARID CLIMATIC GRADIENT IN NORTHEAST SPAIN
}

\author{
SERGIO M. VICENTE-SERRANO ${ }^{\mathrm{a}, *}$ and JUAN I. LÓPEZ-MORENO ${ }^{\mathrm{a}, \mathrm{b}}$ \\ ${ }^{a}$ Instituto Pirenaico de Ecología, CSIC (Spanish Research Council), Campus de Aula Dei, PO box 202, Zaragoza 50080, Spain \\ ${ }^{\mathrm{b}}$ Department of Geosciences, University of Fribourg, Perolles, CH-1700, Switzerland
}

\begin{abstract}
This paper analyses the spatial and temporal variability of winter droughts in a semi-arid geographic gradient in Northeast Spain, from the Pyrenees in the north to the Mediterranean coastland in the south. Droughts that occurred between 1952 and 1999 were analysed by means of the Standardised Precipitation Index (SPI). The influence of the weather-type frequency and of the general North Atlantic atmospheric circulation patterns was analysed. The results indicate that winter droughts show an important spatial variability in the study area, differentiating three well-defined patterns. These correspond to the Pyrenees, the centre of the Ebro Valley, and the Mediterranean coastland. General negative trends in winter SPI have been found, which are indicative of the increase in winter drought conditions in the study area. Nevertheless, important spatial differences have also been recorded. Dominant north-south gradients in the influence of weather types are shown. Moreover, the negative trends in winter-SPI values agree with the negative trend in the frequency of the weather types prone to cause precipitation, such as the $\mathrm{C}, \mathrm{SW}$ and $\mathrm{W}$ weather types and the increase in the frequency of A weather types. Nevertheless, in the Mediterranean coastland, the positive trend in SPI values agrees with the increase in the frequency of weather types of the east (E, SE), which are prone to cause precipitation in this area. Interannual variations in the frequency of the different weather types have been highly determined by different general atmospheric circulation patterns, mainly the North Atlantic Oscillation (NAO). Nevertheless, the correlation between the time series of weather-type frequency and the winter SPI is higher than that found between the SPI and the NAO. Thus, although the interannual NAO variability explains a high percentage of the interannual differences in the frequency of different weather types, it is not sufficient to explain the spatial and temporal variability of droughts, which respond better to atmospheric variability at more detailed (synoptic) spatial scales.
\end{abstract}

KEY WORDS: synoptic climatology; weather types; North Atlantic Oscillation; drought; Standardised Precipitation Index; winter season; Ebro Valley; Spain

\section{INTRODUCTION}

Drought is one of the main climatic hazards that affect arid and semi-arid regions. It can essentially be considered a climatic phenomenon (Palmer, 1965; Beran and Rodier, 1985), since droughts are usually related to an abnormal decrease of precipitation. Although high temperatures, wind flows and low air moisture can reinforce water shortages, it is usual to consider only precipitation data when recognising and analysing droughts (McKee et al., 1993; Guttman, 1998; Keyantash and Dracup, 2002).

Several negative effects are associated with drought in the Iberian Peninsula: (1) losses in agriculture (Austin et al., 1998; Molinero, 2001); (2) damage to natural ecosystems (Vicente-Serrano, 2004; López-Bermúdez and Alonso, 2001); (3) an increase in forest fire risk (Pausas, 2004); (4) degradation of soils and desertification (López-Bermúdez, 1985); and (5) social alarm (Morales et al., 2000).

\footnotetext{
* Correspondence to: Sergio M. Vicente-Serrano, Instituto Pirenaico de Ecología, CSIC (Spanish Research Council), Campus de Aula Dei, PO box 202, Zaragoza 50080, Spain; e-mail: svicen@ipe.csic.es
} 
Drought studies have received special attention in recent years because of climate change. The atmospheric causes of droughts have been analysed widely in order to improve drought prediction (Cordery and McCall, 2000; Lloyd-Hughes and Saunders, 2002a). In the Mediterranean region, climatic models indicate an important decrease in precipitation (higher than $30 \%$ ) for the twenty-first century if $\mathrm{CO}_{2}$ levels continue to rise (Houghton et al., 2001). Thus, it is necessary to improve our understanding of the atmospheric factors that determine the spatial and temporal variability of droughts in these regions to determine in greater depth the possible consequences of climatic change.

The influence of synoptic atmospheric circulation on the frequency and intensity of precipitation is very important (Yarnal and Frakes, 1997). For this reason, efforts have been dedicated to the development of classification methods based on different catalogues of weather types (Yarnal et al., 2001). The synoptic spatial scale has been widely used for regional precipitation modelling (Romero et al., 1999; Phillips and McGregor, 2001; Svensson et al., 2002; Santos et al., 2005). Moreover, in different regions, evidence has been provided about relationships between weather-type frequency and general atmospheric circulation patterns (Wilby, 1993; Fraedrich, 1994; McCabe and Muller, 2002; Stefanicki et al., 1998; Sheridan, 2003). In fact, it could be said that the general atmospheric circulation variability is driven regionally by means of a series of weather types, which would explain in physical terms the intensity and spatial distribution of precipitation.

Different studies have analysed the influence of weather-type frequency on precipitation in different Mediterranean regions, mainly for intense precipitation events (Romero et al., 1999; Kahana et al., 2002, 2004; Esteban et al., 2005). Nevertheless, a few studies on the influence of the frequency and persistence of weather types on droughts in this region have been published (Delitala et al., 2000; Olcina, 2001; Brunetti et al., 2002). The persistence of blocking-anticyclone cellules is the general condition that causes absence of precipitation in the western Mediterranean region (Delitala et al., 2000). In this area, Maheras and KolyvaMachera (1990) indicated that humid periods are related to meridian circulation modes, whereas the dry periods are related to zonal circulation.

Several papers have indicated that interannual precipitation variability and drought occurrence in Spain are related to changes in the main atmospheric circulation modes on global and hemispheric spatial scales (von Storch et al., 1993; Rodríguez-Puebla et al., 1998; Rodó et al., 1997; Pozo-Vázquez et al., 2001, 2004; Martín-Vide and Fernández, 2001). Other papers have analysed the influence of weather types on precipitation (Trigo and DaCamara, 2000; Goodess and Palutikof, 1998; Martín-Vide, 2002; Goodess and Jones, 2002;

Corte-Real et al., 1998; Esteban et al., 2005). Nevertheless, at present there is no joint analysis of the relationship between the general atmospheric circulation modes in the North Atlantic region, the weathertype frequencies and the intensity and spatial differences of droughts, nor have detailed spatial scales been considered by means of a high density of weather stations, a method that would make it possible to accurately determine spatial and temporal patterns in a region of strong precipitation variability.

The present study considers a north-south gradient in Northeast Spain to take into account different climatic and geographic environments, from mountains in the north (the Pyrenees) to the coastland Mediterranean area. The objectives were to determine the role of atmospheric circulation at different spatial scales on spatial and temporal variability of droughts. The study was carried out between 1952 and 1999 with a homogeneous and dense network of weather stations. Winter season (December-February) was selected for the analysis because the influence of atmospheric circulation variability on precipitation is higher (von Storch et al., 1993; González-Rouco et al., 2000), and winter precipitation is the most important factor in this region to explain the interannual variability of reservoir storages (López-Moreno et al., 2002, 2005), river flows (López-Moreno and García-Ruiz, 2004), crop productions (Austin et al., 1998) and vegetation activity (Vicente-Serrano et al., 2004a).

\section{METHODS}

\subsection{Analysis of the temporal variability of the winter atmospheric circulation}

2.1.1. Weather-type classification. Different subjective weather-type classifications have been developed for the Iberian Peninsula (Linés, 1981; Capel, 2000; Ruiz, 1982). However, automatic methods of classification 
make it possible to maintain homogeneity over time and to create daily series of weather types for long periods. Automatic classifications are based on statistical techniques such as k-mean clustering (Matyasovszky et al., 1993), correlation (Yarnal, 1993), principal component analysis (PCA, Kutzbach, 1970; Deser and Blackmon, 1993; Wallace and Gutzler, 1981) or fuzzy rules (Pesti et al., 1996). Romero et al. (1999) used a PCA in T-mode for weather-type classification in the Iberian Peninsula and, in the same region (Corte-Real et al. (1998); Rasilla (2002) and Esteban et al. (2005), used an algorithm that combines the k-mean clustering and the PCA for the same purpose.

Other methods are based on catalogues of atmospheric circulation type. The most widely used method is the one formulated by Jenkinson and Collison (1977), based on the Lamb catalogue (Lamb, 1972). This has been applied in several regions such as the United Kingdom (Hulme et al., 1993; Wilby et al., 1995; Jones et al., 1993), USA (Wilby and Wigley, 1997), Scandinavia (Linderson, 2001) and Japan (Wilby et al., 1998). In the Iberian Peninsula, it has been widely used to classify weather types (Martín-Vide, 2002; Goodess and Palutikof, 1998; Goodess, 2000; Goodess and Jones, 2002; Trigo and DaCamara, 2000; Rasilla et al., 2002; Spellman, 2000a,b).

A precise description of the classification method can be found in Jenkinson and Collison (1977) or in Jones et al. (1993). Jones et al. (1993) and Linderson (2001) used a sea-surface pressure grid of 16 points centred over Great Britain and Denmark, respectively, to perform the classification. Rasilla et al. (2002) transposed this grid to the Iberian Peninsula (Figure 1). From daily pressure data at these points between 1951 and 1999, and using the Jenkinson and Collison method, we calculated the direction of surface wind and its vorticity in geostrophic units $(\mathrm{hPa})$. These parameters indicate the type and direction of winds (cyclonic/anticyclonic, directional and hybrid), which later allows classification of weather types. We used the NCEP-NCAR daily surface pressure data set for this analysis (http://dss.ucar.edu/catalogs/gridlists/sel_gslp.html\#a, Trenberth and Paolino, 1981; Basnett and Parker, 1997).

Martín-Vide (2002) indicated that Jenkinson and Collison's method for weather-type classification in the Iberian Peninsula has some shortcomings. A proportion of $18.4 \%$ of the days are not classified in any group. Nevertheless, Martín-Vide indicates that this fact is recorded mainly in summer and autumn owing to the low-pressure gradient that characterise these months in the Iberian Peninsula. Rasilla et al. (2002) reclassified the non-classified days according to the mean surface pressure: days with over $1020 \mathrm{hPa}$ are classified as anticyclonic and those under $1020 \mathrm{hPa}$ as cyclonic. We followed the same approach and eliminated the nonclassified days. Another problem of Jenkinson and Collison's method for weather-type classification in the Iberian Peninsula is related to the absence of pressure data at other levels (i.e. $500 \mathrm{hPa}$ ). This causes a high number of cyclonic days during the summer months to be obtained as a consequence of frequent low pressures at surface level (thermic) during this season (Capel, 2000). Nevertheless, this problem does not affect the present study as it was carried out in the winter.

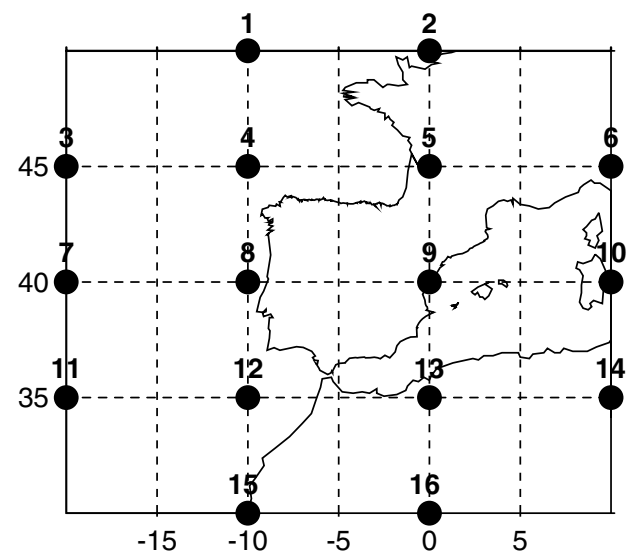

Figure 1. Pressure grid used for weather type classification 
Usually, droughts are quantified monthly because this phenomenon needs prolonged precipitation shortages over the course of long periods to be identified. Fowler and Kilsby (2002) analysed the persistence and intensity of droughts as a function of weather-type frequency in the east of England. These authors obtained quantitative monthly series from the daily weather types by means of the sum of the number of weather types of each class during the month. Corte-Real et al. (1998) used the same approach to summarise the monthly frequency of weather types in Portugal. In this paper, we followed this approach to create numerical monthly series of the frequency of each weather type. The 26 weather types obtained by means of Jenkinson and Collison's method were summarised by means of the elimination of hybrid types, which were reclassified at $50 \%$ to cyclonic (C), anticyclonic (A) or directional weather types (N, north; NE, northeast; E, east; SE, southeast; S, south; SW, southwest; W, west and NW, northwest) (Jones et al., 1993; Trigo and DaCamara, 2000).

2.1.2. General atmospheric circulation patterns. The general atmospheric circulation patterns show less temporal variability than weather types. Although some studies show changes around 8-10 days in the phase of the general atmospheric circulation patterns (Feldstein, 2000), the persistence of general conditions can be maintained for periods of months or years. Hurrell (1995) indicated that the North Atlantic Oscillation (NAO) shows a persistence of negative or positive phases for years. Therefore, the temporal variability of weather types would be set within the general atmospheric circulation patterns, which are more general and less variable in time and space. Barnston and Livezey (1987) showed, in the Northern Hemisphere, nine general atmospheric circulation patterns in winter and three in summer, spring and autumn, and also identified a pattern (NAO) throughout the year. Trigo and Palutikof (2001) carried out a PCA to determine the general atmospheric circulation patterns in Western Europe, and determined that the main pattern is the NAO, which explains $21 \%, 28 \%$ and $33 \%$ of total atmospheric circulation variability in spring, autumn and winter, respectively.

The NAO affects winter precipitation significantly in the Iberian Peninsula (Trigo et al., 2004; Ullbrich et al., 1999; Martín-Vide and Fernández, 2001). Nevertheless, other atmospheric circulation patterns can be identified during the boreal winter in Western Europe (Barnston and Livezey, 1987). These patterns have an important role in the climatology of the western Mediterranean area (Marshall et al., 2001; Rodríguez-Puebla et al., 1998; Krichak and Alpert, 2005; Dünkeloh and Jacobeit, 2003).

In this paper, we have considered the circulation indices that explain the main atmospheric circulation patterns in the North Atlantic region: the NAO, the East Atlantic (EA) Pattern, the East Atlantic/West Russian (EA/WR) Pattern and the Scandinavian (SCA) Pattern. To quantify the NAO, we used the index made by the Climate Research Unit (University of East Anglia) (http://www.cru.uea.ac.uk/cru/data/nao.htm, Jones et al., 1997). The other indices were obtained from the National Centers for Environmental Prediction (NCEP) of the USA (ftp://ftpprd.ncep.noaa.gov/pub/cpc/wd52dg/data/indices/tele_index.nh), which were obtained by means of PCA according to Barnston and Livezey (1987).

\subsection{Winter drought quantification}

2.2.1. Database. The study was carried out in a north-south gradient in Northeast Spain, from the Mediterranean Sea to the Pyrenees (Figure 2). Differences in topography are very important within the study area. The north corresponds to the Pyrenean Mountains, where $3000 \mathrm{~m}$ a.s.1. are exceeded. The climate of this area is characterised by humidity (mean winter precipitation is higher than $400 \mathrm{~mm}$ ) and cold temperatures (Cuadrat, 1999). The centre of the study area is a well-defined geographic region, the Central Ebro Valley, with an elevation range between 250 and $600 \mathrm{~m}$, which is one of the most arid regions of Europe (annual precipitation does not exceed $400 \mathrm{~mm}$, and winter precipitation is less than $100 \mathrm{~mm}$ ). The aridity, along with the continental features of the climate, causes an important constraint for vegetation and human activities (Austin et al., 1998; Pedrocchi, 1998). The south of the study area corresponds to the north of the Valencia region, close to the Mediterranean Sea, where temperatures are milder than in the centre of the Ebro Valley (Pérez-Cueva, 1994) and precipitation is higher owing to the influence of the Mediterranean (Camarasa, 1993; Millán et al., 1995). 

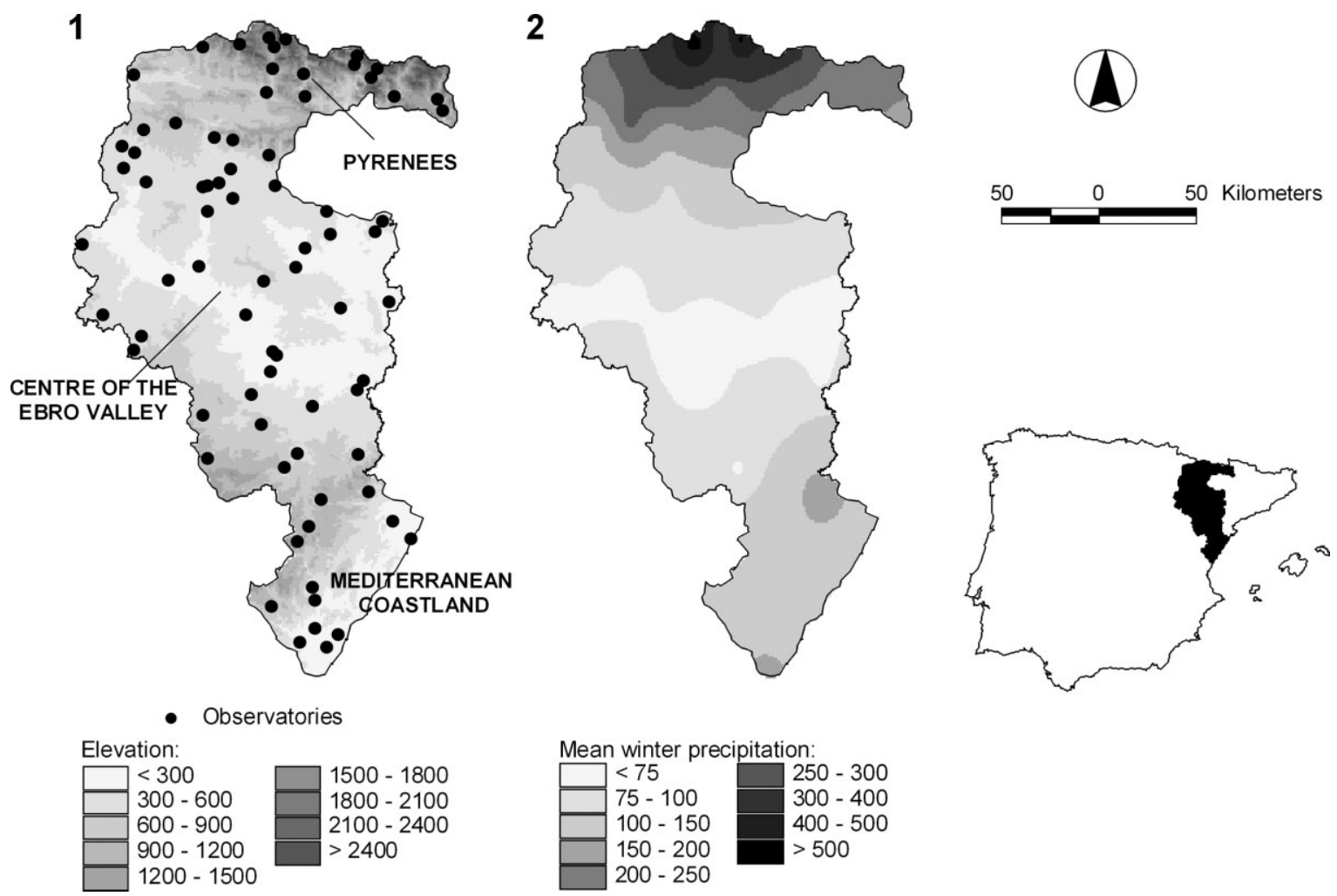

Figure 2. Spatial distribution of observatories, elevation (1) and winter mean precipitation (2) in the study area

For analysis, we used 75 monthly precipitation observatories in this region, from 1951 to 1999 . These observatories were selected from a dense database of more than 400 observatories obtained from the National Institute of Meteorology (Spain). Some series had to be created by combining data from different observatories within the same locality, owing to the frequent changes of location of Spanish observatories during the twentieth century. The 75 observatories selected had less than 15\% loss of data between 1951 and 1999. Eighteen of these series were created by merging different series of the same locality, which cover different periods. The data were subjected to a process of quality control that identified anomalous records using a quartile-based range statistic, in line with González-Rouco et al. (2001). Owing to the creation of some of the series by means of merging two or more observatories of the same locality, and to guarantee the final quality of the precipitation series, the homogeneity of each one was checked (Peterson et al., 1998; Lanzante, 1996) against an independent reference series that was generated by selecting five of the series whose difference series correlated best with the difference series in question (Peterson and Easterling, 1994). The average correlation coefficient between the five most correlated series of each observatory and the objective series was 0.82 . Moreover, the minimum correlation obtained for a series that was included in a reference series was 0.66 . Thus, the values above 0.75 are considered dominant, which implies a high reliability of the reference series created.

To test the homogeneity of the series, the Standard Normal Homogeneity Test was used (SNHT, Alexandersson, 1986; Alexandersson and Moberg, 1997), a technique widely applied in the homogenisation of climate records in several areas (Keiser and Griffiths, 1997; Moberg and Bergstrom, 1997; González-Hidalgo et al., 2002). For this purpose the ANCLIM program was used (Štìpánek, 2004). Only seven nonhomogeneous series were identified and corrected using the difference between the average of the records before and after the date of the inhomogeneity was identified, in line with Alexandersson and Moberg (1997). Finally, temporal gaps were completed after homogenisation using linear regressions with respective reference series (Štìpánek, 2004). 
2.2.2. Drought index calculation. In the last decade, the most popular drought index has been the Standardised Precipitation Index (SPI), which is valued for its theoretical development, robustness and versatility in drought analysis. The SPI was developed by McKee et al. $(1993,1995)$ to identify non-normal dry and humid periods more precisely than others. The SPI only needs precipitation data for its calculation (Guttman, 1998, 1999). Keyantash and Dracup (2002) tested the robustness of 18 different drought indices by means of statistical methods, and concluded that the SPI is the best climatic index for drought identification and for quantification of the severity, duration and spatial extent of droughts. Although the development of the SPI is recent, this index has been used for drought analyses in many areas, including the USA (Hayes et al., 1999), Europe (Lloyd-Hughes and Saunders, 2002b), South Africa (Rouault and Richard, 2003), Hungary (Domonkos, 2003), Italy (Bonaccorso et al., 2003), East Africa (Ntale and Gan, 2003), Greece (Loukas and Vasiliades, 2004), Germany (Bordi et al., 2004) and Korea (Min et al., 2003).

Guttman (1999) examined the properties of the SPI in further depth and described the effects of using different stochastic models. He concluded that Pearson III distribution is better for calculating the SPI because its three parameters allow more flexibility than the two parameters of the Gamma distribution.

The probability density function of a Pearson III distributed variable is written as

$$
f(x)=\frac{1}{\alpha \Gamma(\beta)}\left(\frac{x-\gamma}{\alpha}\right)^{\beta-1} e^{-\left(\frac{x-\gamma}{\alpha}\right)}
$$

where $\alpha, \beta$ and $\gamma$ are the shape, scale and origin parameters, respectively, for precipitation values $x>0$. $\Gamma(\beta)$ is the Gamma function of $\beta$. The calculation of parameters was carried out by means of the L-moment method. Hosking (1990) and Sankarasubramanian and Srinivasan (1999) have discussed the advantages of Lmoments in the estimation of distribution parameters. For small samples (fewer than ten cases) the difference between using moments or L-moments is small, but when the size of the sample increases, and with highly biased distributions, the reliability of L-moments is higher (Sankarasubramanian and Srinivasan, 1999).

The Pearson III distribution is not defined for $x=0$, which is a problem, considering that precipitation series can include months in which there is no precipitation. With this in mind, an adapted statistic $H(x)$ can be calculated using the following formula:

$$
H(x)=q+(1-q) F(x)
$$

where $q$ is the probability of precipitation $=0$ and $F(x)$ is the cumulative probability of a precipitation of magnitude $x$ following a Pearson III distribution. Edwards and McKee (1997) suggests that $q$ can be calculated simply as $m / n$, where $n$ is the overall number of months and $m$ is the number of months in which precipitation is 0 .

Once $H(x)$ is calculated, it is normalised so that the mean is 0 and standard deviation is 1 . This normalised variable is interchangeable with the SPI, and is commensurable with other SPI values over time and space. An SPI of 0 indicates precipitation corresponding to $50 \%$ of the accumulated probability according to the Pearson III distribution. The complete formulation of the SPI calculation according to the Pearson III distribution and the L-moment method can be found in Vicente-Serrano and Cuadrat (2002) and Vicente-Serrano (2006).

\subsection{Analysis of drought spatial and temporal patterns}

To determine the general patterns of temporal evolution in the winter-SPI series, we used a PCA, which is widely used to analyse spatial and temporal patterns of droughts in different regions (Karl and Koscielny, 1982; Eder et al., 1987; Bonaccorso et al., 2003; Vicente-Serrano et al., 2004b; Vicente-Serrano, 2006). To summarise the general temporal patterns of droughts in the study area, we used a PCA in S-mode (Serrano et al., 1999), in which observatories are the variables and years the different cases. The S-mode allows determination of regions in which the structure of evolution of winter droughts is the same. Components obtained were rotated (Varimax) to obtain more stable patterns, maintaining the orthogonal structure of components (Richman, 1986). Because the SPI is a standardised variable, the components obtained can be identified as the regional SPI of a representative region (Lana et al., 2001). 
Trends in the different variables were analysed by means of Spearman's rank correlation test because it is less affected by the presence of outliers and non-normality of the series (Lanzante, 1996). For temporal change detection in climatology, the moving average procedure is a conventional procedure (Sneyers, 1990). This procedure allows filtering the year-to-year variations to reveal more persistent trends (Wheeler and Martín-Vide, 1992; Salinger et al., 1995; De Luis et al., 2000). For this reason, prior to trend analysis, the different variables were smoothed by means of a moving average of 9 years, following De Luis et al. (2000). The smoothing procedure decreases the degrees of freedom of the series because it reduces the number of samples (from 49 to 41 records), but it also reduces the higher frequency variability (noise) that can hide existing trends.

Finally, to assess the role of atmospheric circulation on spatial and temporal patterns of droughts, we obtained correlation coefficients (R-Pearson) between the non-filtered time series of the components and the SPI series in each observatory as well as the time series of weather-type frequency and the teleconnection indices. In the case of observatories, we continuously mapped the R-Pearson coefficients to determine the spatial differences in the role of atmospheric circulation on droughts in the study area. For this purpose we used an algorithm of splines with tension (Mitasova and Mitas, 1993; Vicente-Serrano et al., 2003).

\section{RESULTS AND DISCUSSION}

\subsection{Winter weather types: characteristics and evolution}

Figure 3 shows the average of the winter frequency in each weather type between 1952 and 1999. The highest frequency corresponds to anticyclonic days (A), with 37 days. The mean of cyclonic days (C) is 12, and the directional weather types show a lower frequency, although the N, SW, W and NW show a higher frequency than the weather types from east and south.

Figure 4 shows the evolution of the number of $\mathrm{A}$ and $\mathrm{C}$ weather types in winter and one example of the evolution of two directional weather types (NE and SW). In the most frequent weather types, such as A and $\mathrm{C}$, there is an important interannual variability, mainly in the frequency of A weather types, with important variations from the maximum (54 days in 1995) to the minimum (17 days in 1996). Also, there are important interannual variations in the number of C days, with a maximum of 25 in 1996 and a minimum of 0 in 1995. Black lines indicate a moving average of 9 years, which, in the case of the A weather types, show a clear increase in the frequency of these weather types from 1952 to 1999. On the other hand, there were clear decreases in the frequency of NE and SW weather types.

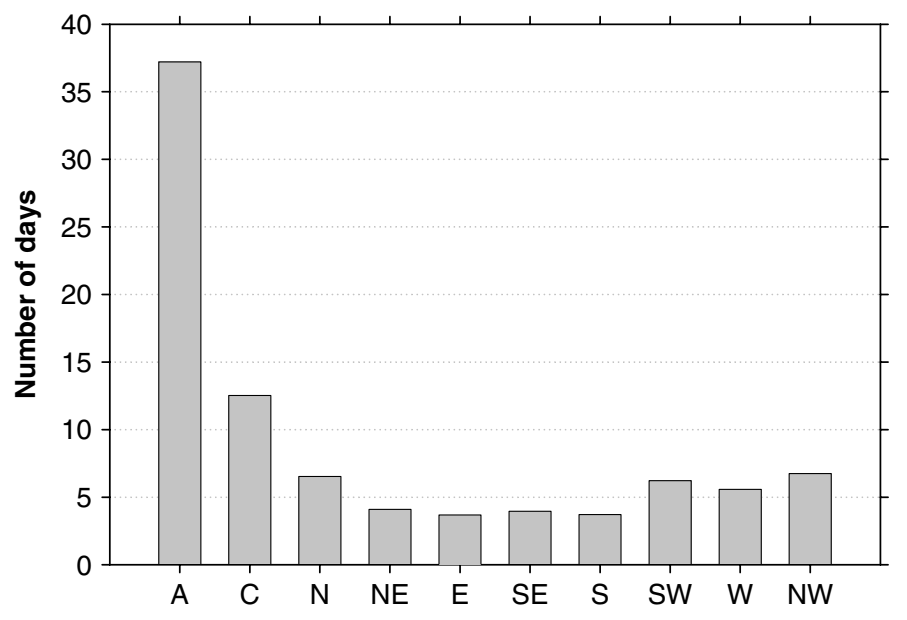

Figure 3. Average frequency of the winter weather types (1952-1999) 

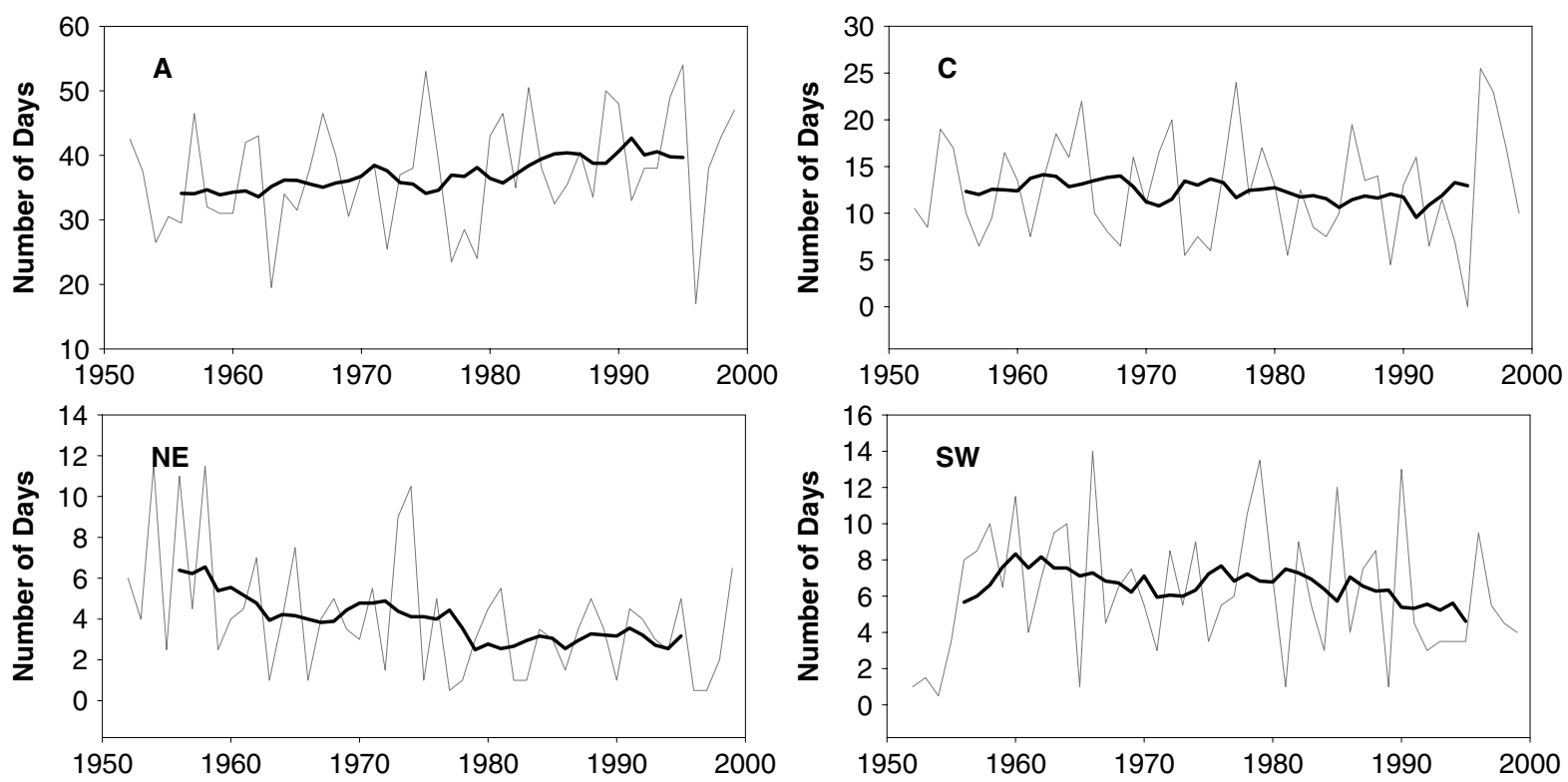

Figure 4. Evolution of the frequency of different weather types. Black line indicates a moving average of 9 years. 1952-1999

Table I. Trends in the different winter weather types in the Iberian Peninsula (1952-1999)

\begin{tabular}{lccc}
\hline $\begin{array}{l}\text { Weather } \\
\text { type }\end{array}$ & Rho-Spearman & $\begin{array}{c}\text { Weather } \\
\text { type }\end{array}$ & Rho-Spearman \\
\hline A & $0.87^{\mathrm{a}}$ & SE & $0.54^{\mathrm{a}}$ \\
$\mathrm{C}$ & $-0.45^{\mathrm{a}}$ & $\mathrm{S}$ & $-0.38^{\mathrm{b}}$ \\
$\mathrm{N}$ & $-0.62^{\mathrm{a}}$ & $\mathrm{SW}$ & $-0.52^{\mathrm{a}}$ \\
$\mathrm{NE}$ & $-0.81^{\mathrm{a}}$ & $\mathrm{W}$ & -0.31 \\
$\mathrm{E}$ & $0.32^{\mathrm{b}}$ & $\mathrm{NW}$ & -0.26 \\
\hline
\end{tabular}

${ }^{\text {a }}$ Significant trend $(\alpha<0.01)$.

${ }^{\mathrm{b}}$ Significant trend $(\alpha<0.05)$.

Table I shows the trend in the frequency of each weather type, considering the moving averages of 9 years. There is a positive and statistically significant trend in the frequency of A days and a decrease, although of lower magnitude, in the frequency of $\mathrm{C}$ days. In relation to the evolution of the directional weather types, between 1952 and 1999 there was a decrease in the frequency of $\mathrm{N}$ types and an increase in the weather types of the east (E and SE). A decrease was also recorded in the frequency of the west weather types, statistically significant in the case of the SW type.

In general, there was an increase in the frequency of weather types that indicate atmospheric stability and high pressures on the Iberian Peninsula, such as the A, E and SE weather types, whereas there was a decrease in the frequency of weather types that indicate low pressures, such as the C and SW types.

Figure 5 shows the average of pressure anomalies in relation to average winter surface pressure in the days classified as A (1), C (2), SE (3) and SW (4). The A and SE weather types, whose frequency shows a positive and significant increase between 1952 and 1999, indicate the influence of high relative pressures centred on the Iberian Peninsula, while the $\mathrm{C}$ and SW weather types, which have a negative trend, show low relative pressures in this region. The increase in the frequency of weather types characterised by atmospheric stability is related to the increase in the atmospheric surface pressures. This has been identified in the Mediterranean 

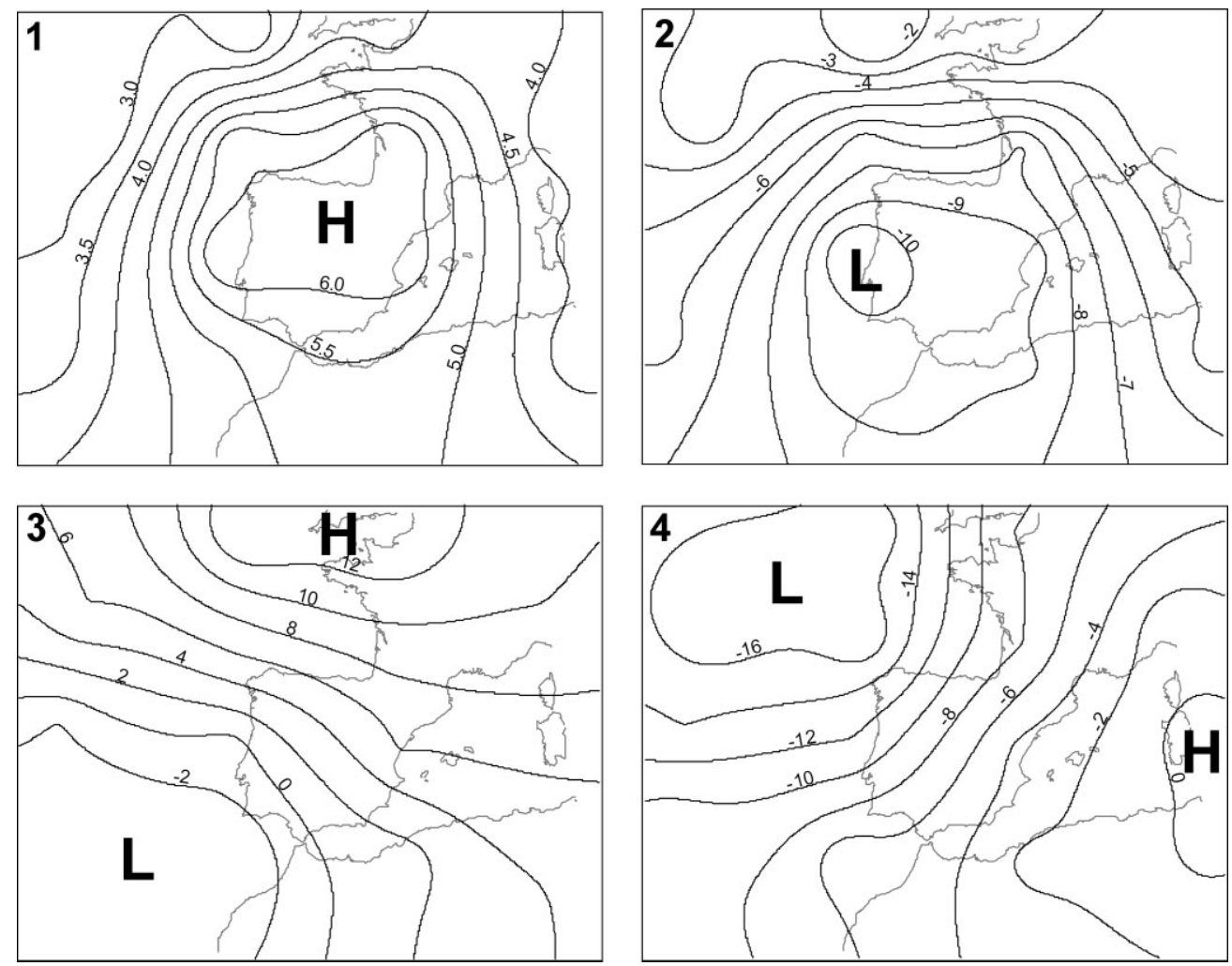

Figure 5. Average of pressure anomalies in relation to average winter surface pressure in the days classified as A (1), C (2), SE (3) and SW (4). L: Low pressures, H: High pressures

region, where there were significant increases of sea-level pressures in the last decades of the twentieth century. Crisciani et al. (1994) showed a significant increase in sea-level surface pressure in Italy between the 1970s and 1990s. In the centre of the Iberian Peninsula, Labajo et al. (1998) indicated an abrupt change in sea-level pressure in the $1970 \mathrm{~s}$, with a significant increase of $0.06 \mathrm{mmHg} / \mathrm{year}$.

The evolution of the winter weather types in the Iberian Peninsula agrees with the evolution of sea-level surface pressure and also with the evolution of the weather types in the Mediterranean region, as indicated by other authors. Trigo and DaCamara (2000) showed a decrease in the frequency of cyclonic weather types in Portugal, the same as Piervitali et al. (1997) and Brunetti et al. (2000) showed in Italy. Amanatidis et al. (1993) indicated a general increase in the northern flows in the eastern Mediterranean region and an increase of the southern flows in the western areas. Corte-Real et al. (1998) indicated that the general decrease in precipitation identified in the Iberian Peninsula between 1960 and 1995 (Hisdal et al., 2001) coincides with the decrease in the frequency of weather types prove to generate precipitation $(\mathrm{C}, \mathrm{W}$ and $\mathrm{SW})$ and also with an increase of anticyclonic weather types. Wanner et al. (1997) showed that there has been a zonal increase in circulation in Europe in the winter season since 1965, which caused important north-south pressure gradients and an increase of the frequency of A weather types. Flohn et al. (1993) ascribed the winter increase of zonal flows to the increase of evaporation processes in the tropical oceans as a consequence of the increase in temperature (Jones and Moberg, 2003), which would cause a meridian transport of latent heat from tropical to Mediterranean latitudes.

\subsection{Drought spatial and temporal patterns during the winter season}

The PCA summarised the spatial variability of winter SPI in seven components (Table II). We selected the first four components, which accumulate $83.8 \%$ of the total variance. Figure 6 shows the spatial distribution 
Table II. Results of the Principal component analysis from winter-SPI series

\begin{tabular}{lcc}
\hline Component & $\begin{array}{c}\text { \% of } \\
\text { the } \\
\text { variance }\end{array}$ & $\begin{array}{c}\% \\
\text { Accumulated }\end{array}$ \\
\hline 1 & 26.9 & 26.9 \\
2 & 23.4 & 50.3 \\
3 & 20.9 & 71.2 \\
4 & 12.6 & 83.8 \\
5 & 2.2 & 86.0 \\
6 & 1.8 & 87.8 \\
7 & 1.7 & 89.5 \\
\hline
\end{tabular}
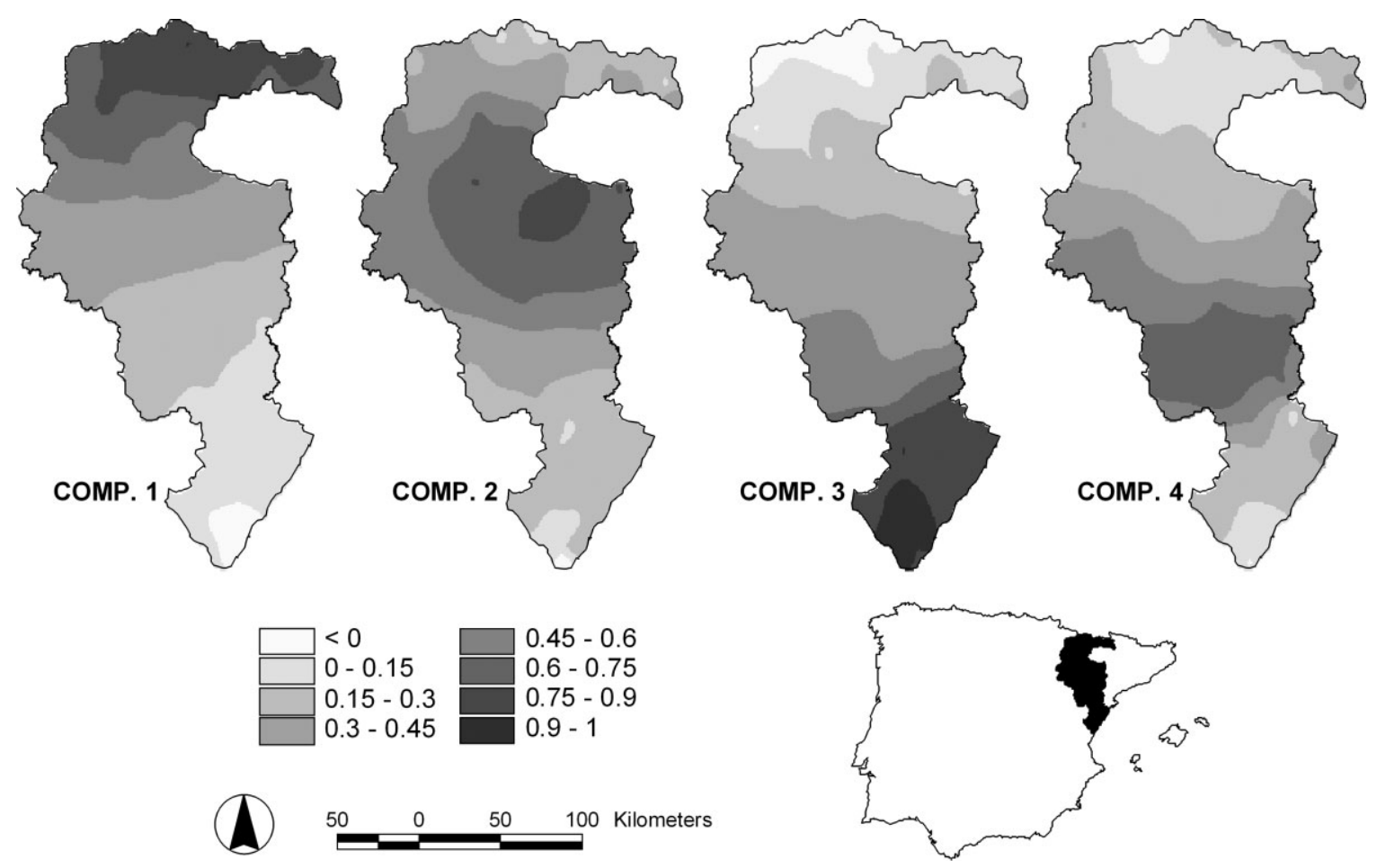

Figure 6. Spatial distribution of loadings from PCA

of the correlation between the winter-SPI series in each observatory and the components. Component 1 (26.9\%) indicates the temporal evolution of the winter-SPI series in the north, corresponding to Pyrenean mountain area. The second component $(23.4 \%)$ shows temporal evolution of winter droughts in the centre of the Ebro Valley. The third component (20.9\%) represents the evolution in the Mediterranean coastland and the fourth component (12.6\%) represents a transitional region between the centre of the Ebro Valley and the Mediterranean coastland. This pattern is less clear, with loadings no higher than 0.6, which indicates that a percentage of drought variance in this region is also explained by the evolution of components 2 and 3 (loadings $>0.4$ in the areas represented by component 4 ), which would confirm the transitional character of this area.

Figure 7 shows the evolution of the four components obtained from analysis. The first component (northern region) shows the most important winter droughts in the decades of 1980s and 1990s and a sharp decrease 

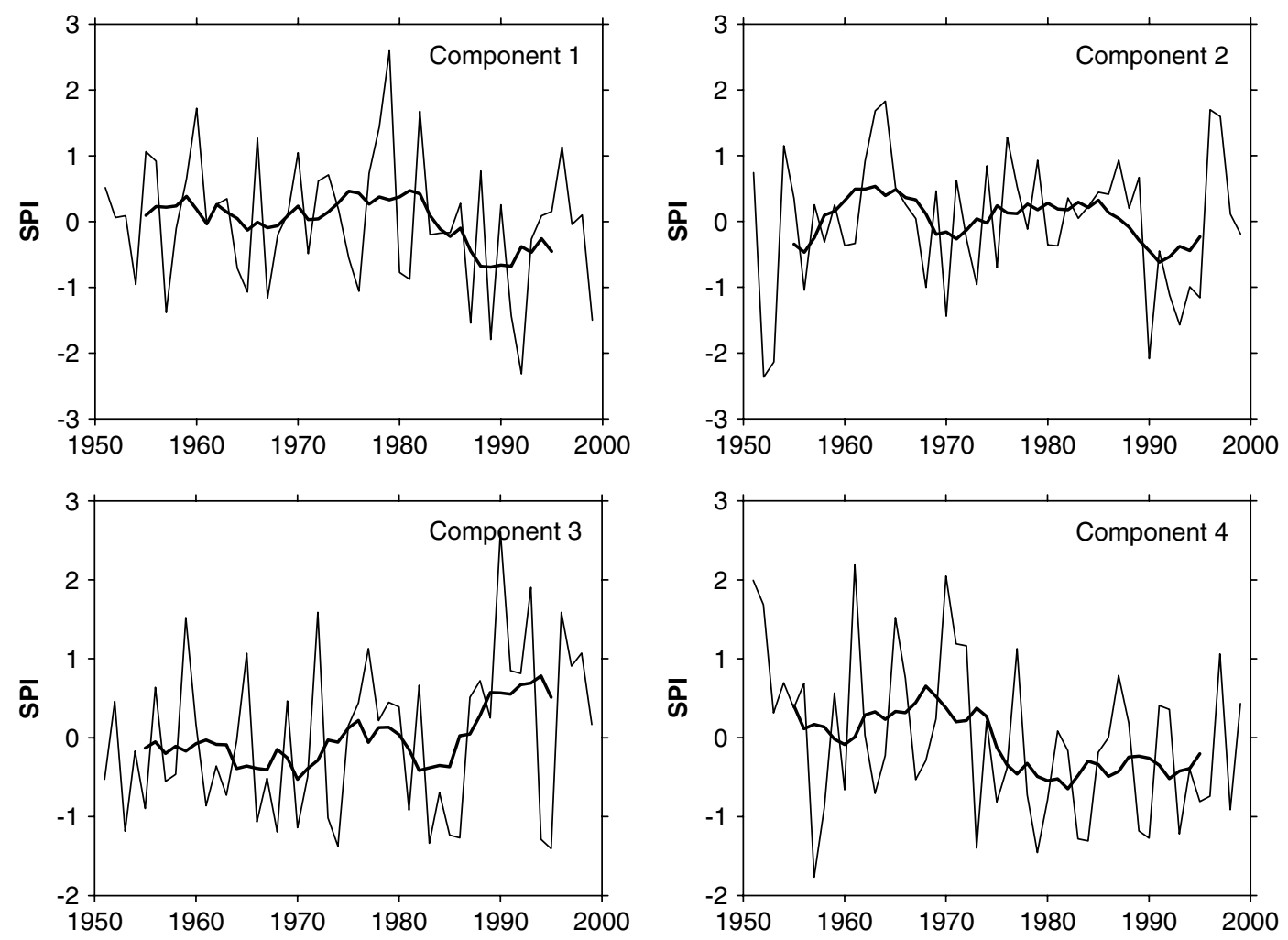

Figure 7. Evolution of four first principal components. Black lines indicate a moving average of 9 years

in winter-SPI values at the beginning of the 1980s. There is a negative and significant trend ( $R h o=-0.49$, $\alpha<0.01$ ) caused by this abrupt change. Component 2 also shows very dry winters between 1989 and 1995 . Moreover, the winters of 1953 and 1954 were also very dry in the centre of the Ebro Valley. This series also shows a negative and significant trend (Rho $=-0.43, \alpha<0.01)$. Component 3 , representative of the Mediterranean coastland, shows an important interannual variability, but the general trend summarised by the 9-year moving average shows the opposite of the other components, with a trend $($ Rho $=0.56, \alpha<0.01)$ to positive values in the last decades of the century. In the 1990s, all the years showed positive SPI values, with the exception of 1994 and 1995. Component 4 shows a negative and significant trend $(R h o=-0.66$, $\alpha<0.01$ ) caused by a sustained and progressive decrease in the SPI values since the decade of 1950s.

The trend in the different observatories is shown in Figure 8. There is a general predominance of observatories in which negative and significant trends have been recorded. Forty-nine observatories showed a significant negative trend at $99 \%$ and seven at $95 \%$. Thirteen observatories had non-significant trends and only eight had a positive trend (three at $95 \%$ and five at 99\%). Nevertheless, the spatial differences in trends are very clear and agree with the results from the PCA series. Observatories with negative trends are concentrated in the centre of the Ebro Valley and the eastern Pyrenean areas. The positive trends are observed close to the Mediterranean Sea, where some observatories with non-significant trends have also been identified, just as in the northwestern area. Nevertheless, although some spatial differences were identified, the general decrease in the winter-SPI values is the main characteristic in the evolution of drought in the study area between 1952 and 1999.

The spatial patterns of SPI show that the evolution between 1952 and 1999 was different among the Northern Pyrenean areas, the centre of the Ebro Valley and the Mediterranean coastland. The important spatial variability of droughts has been identified in several regions between neighbouring areas (Oladipo, 1986; Karl and Koscielny, 1982; Estrela et al., 2000; Bonaccorso et al., 2003). In the Iberian Peninsula, the 


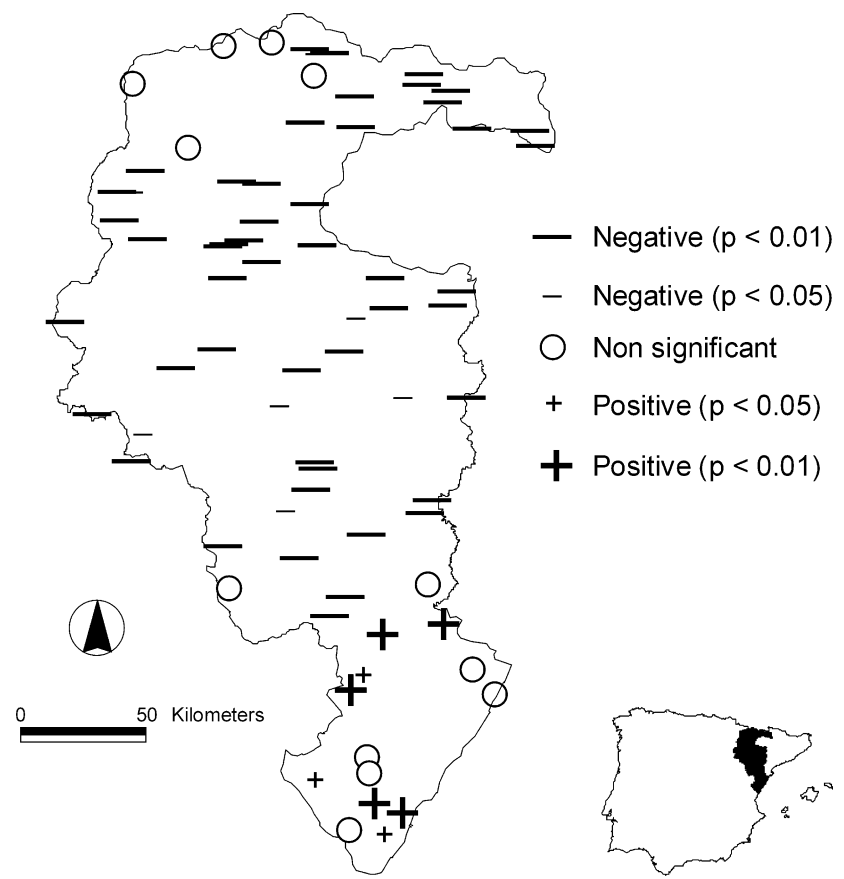

Figure 8. Spatial distribution of trends in winter-SPI values (1951-1999)

differences in temporal evolution of droughts between regions are very important (Vicente-Serrano, 2006). The region analysed here is identified by different authors as a climatic area of transition between the Mediterranean and the Atlantic regions (Fernández-Mills, 1995; Esteban-Parra et al., 1998). The centre of the Ebro Valley coincides with a semi-arid area with important continental characteristics (Cuadrat, 1999). Therefore, the differences in the temporal evolution of droughts are a general characteristic within the study area, with defined patterns and differentiated regions.

Although spatial differences in drought evolution have been recorded, and positive trends have also been recognised in the Mediterranean coastland, the general increase in droughts observed agrees with precipitation trends in other Mediterranean regions. In Spain, the dry period recorded in the 1980s and 1990s has been recorded in Andalusia (Pita, 2001), Catalonia (Rodríguez et al., 1999; Lana et al., 2001) and, in general, in the main part of the Iberian Peninsula (Esteban-Parra et al., 1998). This has also been identified in other Mediterranean regions, such as Italy (Brunetti et al., 2001; Ventura et al., 2002). The 1960s and the 1970s were humid in the main part of the western Mediterranean region (Maheras, 1988), as we observed in the study area.

Some studies in the Mediterranean region have shown a general negative trend in precipitation since the 1960s, which is related to the increase in the succession of dry years. Dry years were concentrated in consecutive years in the last decades of the twentieth century (Hisdal et al., 2001; Szinell et al., 1998). This phenomenon was also identified in the centre of the study area, where the persistence of dry winters was very clear between 1989 and 1995. In the Pyrenees, decrease in winter precipitation led to a marked downtrend of snow accumulation, with several hydrological implications (López-Moreno and García-Ruiz, 2004; López-Moreno, 2005)

\subsection{Influence of weather-type frequency on drought spatial and temporal patterns}

Table III shows the correlation between the SPI series of each component and the series of weather-type frequency. As expected, negative and positive correlations with the frequency of $\mathrm{A}$ and $\mathrm{C}$ weather types, 


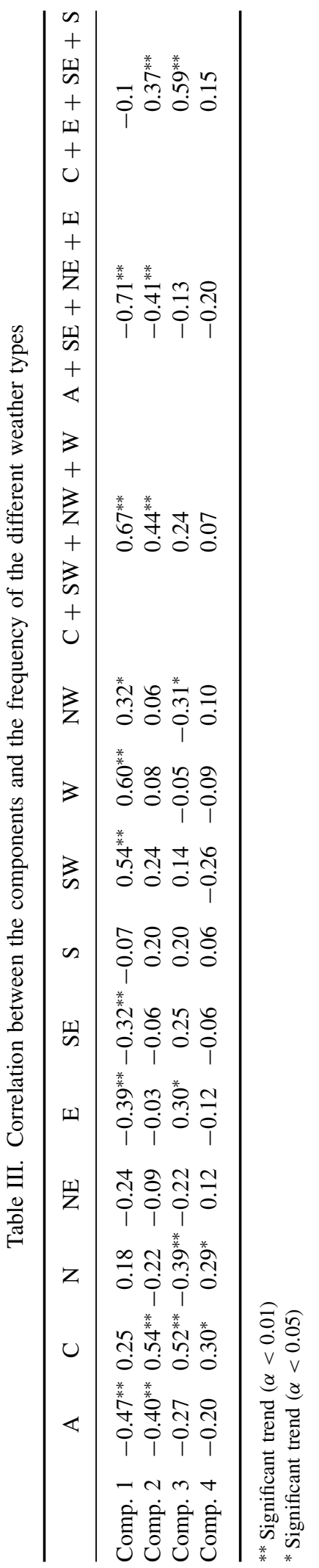


respectively, were found. Nevertheless, correlations are only significant with components 1 and 2 in the case of A weather types, and with components 2, 3 and 4 for $\mathrm{C}$ weather types. The frequency of east weather types shows negative correlations with component 1 (northern region), significant for the $\mathrm{E}$ and SE weathertype frequencies. Nevertheless, for component 3 (Mediterranean coastland), the correlation is positive and statistically significant for the east weather types. We aggregated different weather types according to their influence on components. The sum of the frequency of $\mathrm{C}$ and west directional weather types $(\mathrm{SW}+\mathrm{W}+$ NW) shows a high positive correlation $(R=0.67)$ with component 1 , and the opposite pattern is identified for the sum of $\mathrm{A}$ and east weather types, with a negative and significant correlation $(R=-0.71)$. The sum of west and $\mathrm{C}$ weather types does not increase the correlation in the centre of the study area (Component 2). Nevertheless, the sum of the southeast types $(E+S E+S)$ to $C$ weather types increases the correlation in the case of component 3 (Mediterranean coastland).

Results are confirmed when correlations between weather-type frequency and winter-SPI series in each observatory are mapped continuously. Figure 9 shows the spatial distribution of correlations between the SPI series and the frequency of $\mathrm{C}, \mathrm{A}$ and the sum of some directional weather types. Important spatial differences in the influence of the frequency of the different weather types on winter-SPI values were recorded. Negative and significant correlations were identified in most of the study area with the frequency of A weather types. Nevertheless, correlations are more intense in the centre of the study area. The opposite pattern is shown when considering the frequency of $\mathrm{C}$ weather types, with higher correlations $(R>0.7)$ in the centre of the Ebro Valley. The sum of $\mathrm{A}+\mathrm{NE}+\mathrm{E}+\mathrm{SE}$ shows marked negative correlations with SPI in the north of the study area and non-significant correlations in the Mediterranean coastland. The sum of $\mathrm{C}+\mathrm{SW}+\mathrm{W}+\mathrm{NW}$ weather types indicates positive correlations in the whole of the study area, but higher values are recorded in the northeast $(R>0.7)$. Finally, the sum of $\mathrm{C}+\mathrm{E}+\mathrm{SE}+\mathrm{S}$ weather-type frequency also shows important spatial differences in correlation with the winter-SPI values. Correlation is higher near the Mediterranean Sea, and there is a gradient toward the north of the study area, where non-significant correlations are found.

Figure 10 shows the spatial distribution of correlations between the winter-SPI values and the frequency of the eight directional weather types. Correlations are lower than those for C, A, and the sum of these two directional weather types. Only significant correlations were identified with the SW, W and NW in the north of the study area, with values higher than 0.5 .

In general, spatial patterns of droughts agree with spatial differences in the influence of different weather types in the SPI series. The spatial structure of component 1 (High correlations in the north and low correlations
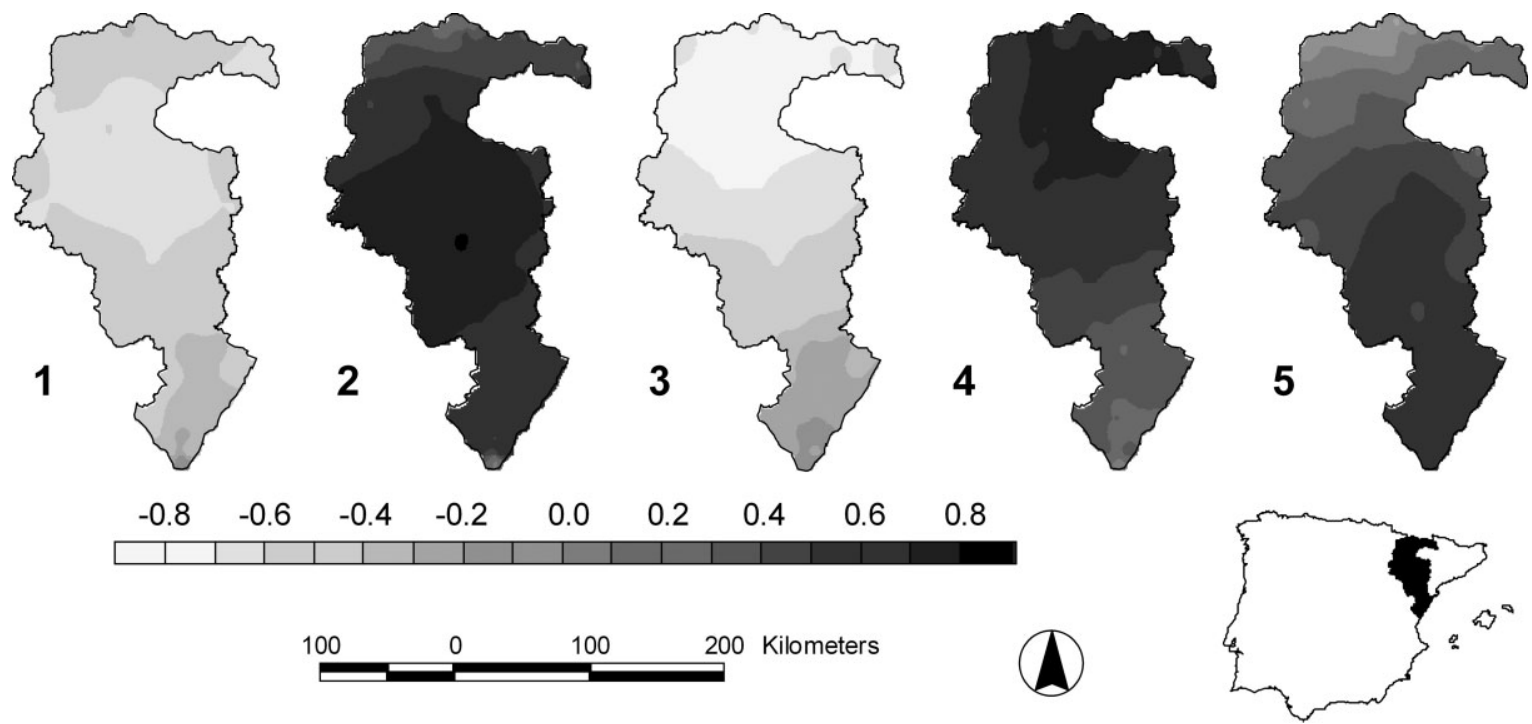

Figure 9. Correlation between the winter SPI and the series of weather-type frequency: 1, A; 2, C; 3, A + E + SE + NE; 4, C + W $+\mathrm{SW}+\mathrm{NW} ; 5, \mathrm{C}+\mathrm{E}+\mathrm{SE}+\mathrm{S}$. Significant correlations correspond to $R$ values higher than 0.29 or lower than $-0.29(\alpha<0.05)$ 

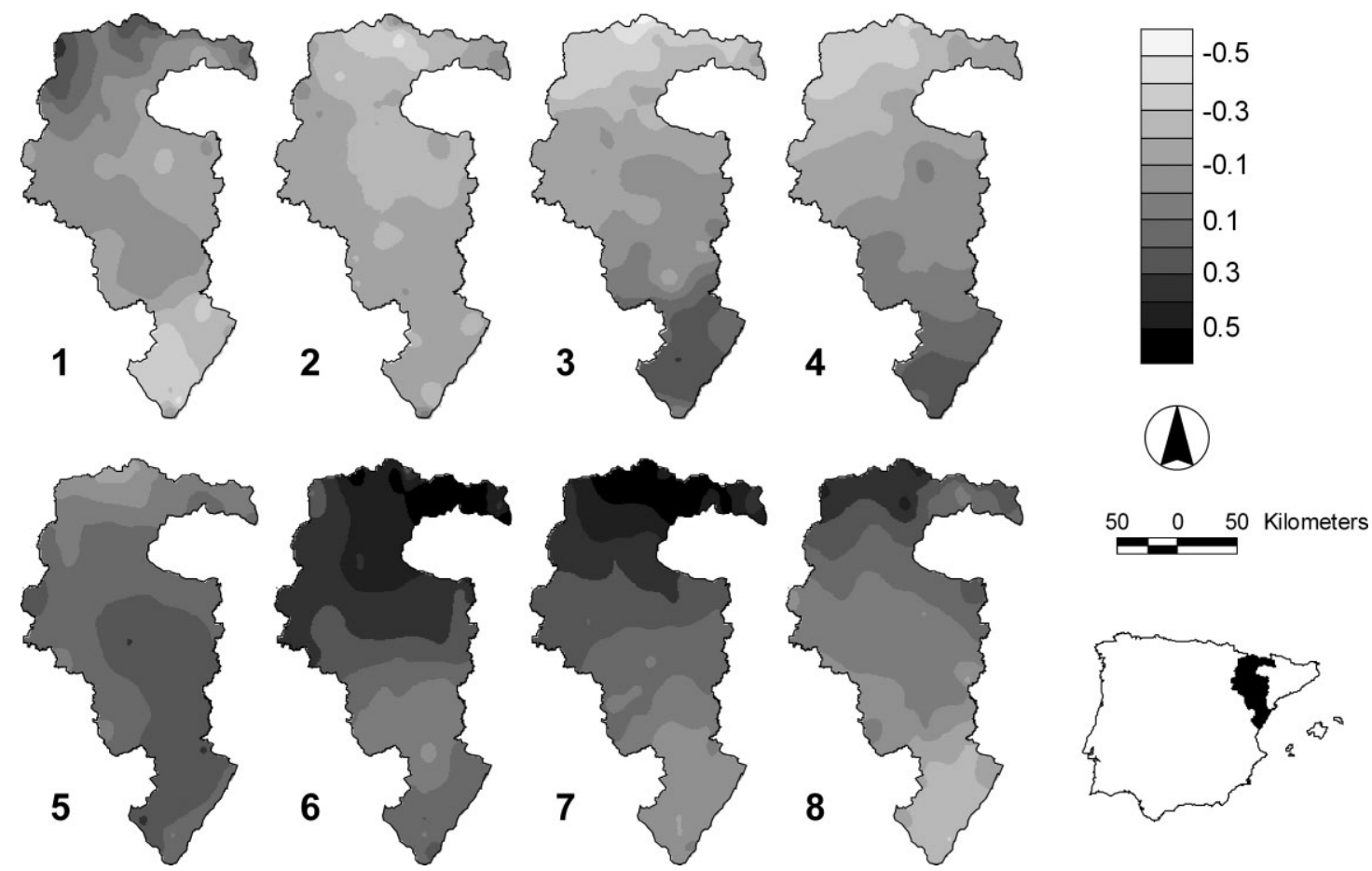

Figure 10. Correlation between the winter SPI and the series of weather-type frequency: 1, N; 2, NE; 3, E; 4, SE; 5, S; 6, SW; 7, W; 8, NW. Significant correlations correspond to $R$ values higher than 0.29 or lower than $-0.29(\alpha<0.05)$

in south) agrees with spatial differences in the influence of the western weather types (NW, W and SW) and also with the sum of the frequency of these weather types and the frequency of the cyclonic weather types. The same was observed with component 2, representative of the centre of the Ebro Valley, with a spatial structure similar to spatial patterns of correlation between the frequency of the $\mathrm{C}$ weather type and the winter SPI. The spatial configuration of component 3 (high correlations in the Mediterranean coastland) agrees with the spatial differences of correlations between the SPI and the sum of $\mathrm{C}+\mathrm{E}+\mathrm{SE}+\mathrm{S}$ weather types. This implies that the spatial differences in the temporal evolution of the winter SPI are related to the evolution of different weather types and their different spatial influence on winter drought conditions.

Olcina (2001) has indicated that the synoptic conditions that usually cause droughts in the Iberian Peninsula correspond to the persistency of different anticyclonic configurations. Martín-Vide (2002) also indicates that the high frequency of flows of the NW or SW causes atmospheric instability and higher precipitations in the Iberian Peninsula. Nevertheless, the complex relief that characterises the Iberian Peninsula and the maritime influence can modulate these influences spatially. In the Mediterranean coastland, different authors have shown that flows from east, and cyclonic weather types have an important role in precipitation (Romero et al., 1999; Goodess and Jones, 2002). Moreover, the flows from east can be reactivated because of hot conditions in the sea-surface temperature, which is frequent in autumn and early winter (Martín-Vide and Llasat, 2000; Serra et al., 1996; Millán et al., 1995). In the centre of the study area, the Ebro Valley, atmospheric influence on precipitation is greatly determined by relief (Creus and Ferraz, 1995). Because of this when the moist W and NW flows come into the valley they are progressively dryer (Creus, 1983). Hence, the W component flows only show significant correlations in the north, near the Atlantic Ocean and in areas with higher elevations. In the centre of the valley, only well-defined cyclonic configurations cause important precipitation.

We also identified significant trends in the frequency of the different weather types in the study area. Moreover, a general negative trend was identified in the winter-SPI values within the study area. The negative trends of $\mathrm{C}, \mathrm{SW}$ and $\mathrm{W}$, which are prone to cause precipitation in the main part of the study area, and the positive trend of $\mathrm{A}$ and east directional weather types, which are negatively correlated with the winter-SPI 
values, could be the cause of the general negative trend of the winter-SPI values. In the whole of the Iberian Peninsula, Goodess and Jones (2002) indicated that the decrease in precipitation is mainly explained by the positive trend towards the occurrence of less-intensive rain days. They indicated that this could be associated with the decrease in the influence of the Atlantic westerly and southwesterly air-masses. Likewise, EstebanParra et al. (1998) indicated that the dry periods of the 1950s and 1990s, which have been identified in large areas of the Iberian Peninsula, were related to an intensification of the Azores anticyclone and a displacement to the east.

Relationships between precipitation trends and the trends in the frequency of different weather types have been indicated in other Mediterranean regions. Corte-Real et al. (1998) and Trigo and DaCamara (2000) indicated that the decrease in the frequency of $\mathrm{C}, \mathrm{SW}$ and $\mathrm{SW}$ weather types was the main cause of the decrease in precipitation observed in Portugal during the second half of the twentieth century. Maheras (1988) indicated that droughts between 1980 and 1985, identified in large areas of the western Mediterranean region, were related to a minimum of $\mathrm{W}$ and SW circulation modes. Brunetti et al. (2000) also identified a negative decrease of precipitation in Italy, which they related to the increase of sea-surface pressure and the higher frequency of anticyclones. Maheras et al. (2000) indicated a connection in the eastern Mediterranean area between the decrease in precipitation and the negative trends in the frequency of cyclonic weather types during the second half of the twentieth century.

Nevertheless, although the general winter-SPI explanation, by means of the evolution in weather-type frequency, agrees with the general results in the Mediterranean region, important spatial differences in winter drought trends have been identified in the study area, in addition to the influence of the different weather types on SPI. Therefore, we also analysed the different roles in the influence of weather types to explain spatial differences in winter-SPI trends.

Table IV shows the mean correlations between the frequency of the different weather types and the winterSPI values in all the observatories located in the study area, grouped according to trends in winter-SPI observed between 1952 and 1999. Non-significant differences in $R$ values between groups were found for C, $\mathrm{NE}$ and $\mathrm{S}$ weather types. The results indicate that negative trends in SPI coincide with negative correlations between the SPI and the frequency of A weather types and with positive correlations between the SPI and the sum of $\mathrm{C}+\mathrm{SW}+\mathrm{W}+\mathrm{NW}$ weather types. Moreover, higher correlations were also identified more with the frequency of SW and W flows than in areas with non-significant or positive trends in winter-SPI values. The opposite behaviour is observed with the sum of $\mathrm{C}+\mathrm{E}+\mathrm{SE}+\mathrm{S}$ weather types, because the highest correlations with the SPI series are recorded in the observatories with positive trends.

Figure 11 shows the distribution of $R$ correlations between the frequency of some weather types and the winter SPI for the different groups of observatories according to SPI trends. Spatial differences in winter-SPI trends are highly related to the increase or decrease in influence of the different weather types.

The results indicate that areas which have experienced a negative trend of winter-SPI values show the highest negative correlations with the frequency of the weather types that experienced a positive trend between 1952 and 1999, such as the A, E and SE weather types. On the other hand, areas with positive trends show lower negative correlations with the frequency of these weather types, and even positive correlations are found. Areas with negative trends also show the highest positive correlations between the SPI and the sum of $\mathrm{C}+$ $\mathrm{SW}+\mathrm{W}+\mathrm{NW}$ weather types whose winter frequency has had a negative trend during the second half of the twentieth century.

\subsection{General atmospheric circulation - weather-type frequency relationships during the winter season in the Iberian Peninsula}

In order to assess the general connection between the winter weather-type frequency variability in the Iberian Peninsula and the general patterns of atmospheric circulation in the North Atlantic area, Table V shows correlations between the winter teleconnection indices of the North Atlantic region and the frequency of the different weather types in the Iberian Peninsula in winter. Different positive and negative correlations were found, but, in general, higher correlations are identified with the NAO index than with the other teleconnection indices. The frequency of $\mathrm{A}$ and $\mathrm{C}$ weather types is highly determined by the winter NAO 


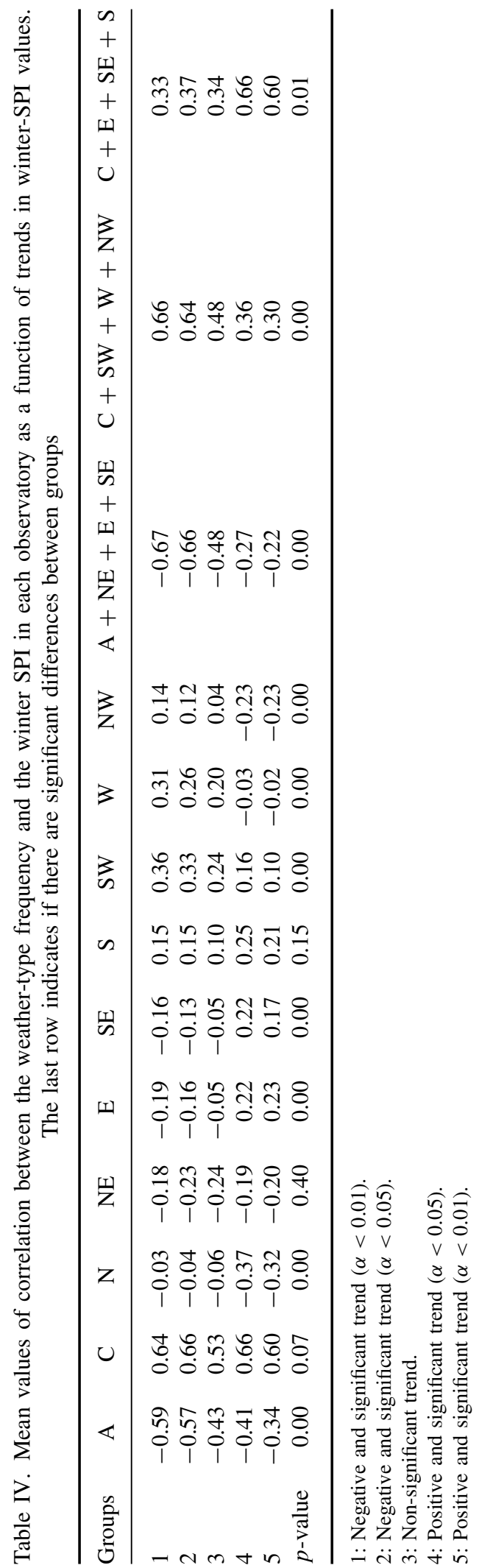


index (Figure 12), but significant and negative correlations between the western weather types (SW and W) and the NAO index were also found.

The EA index shows significant negative correlations with the frequency of the east weather types (E and $\mathrm{SE}$ ), whereas the EA/WR pattern indicates a positive correlation with the frequency of weather types from the east and a negative correlation with the west types. On the contrary, the SCA Pattern shows a positive and significant correlation with the frequency of the SW, W and NW weather types.
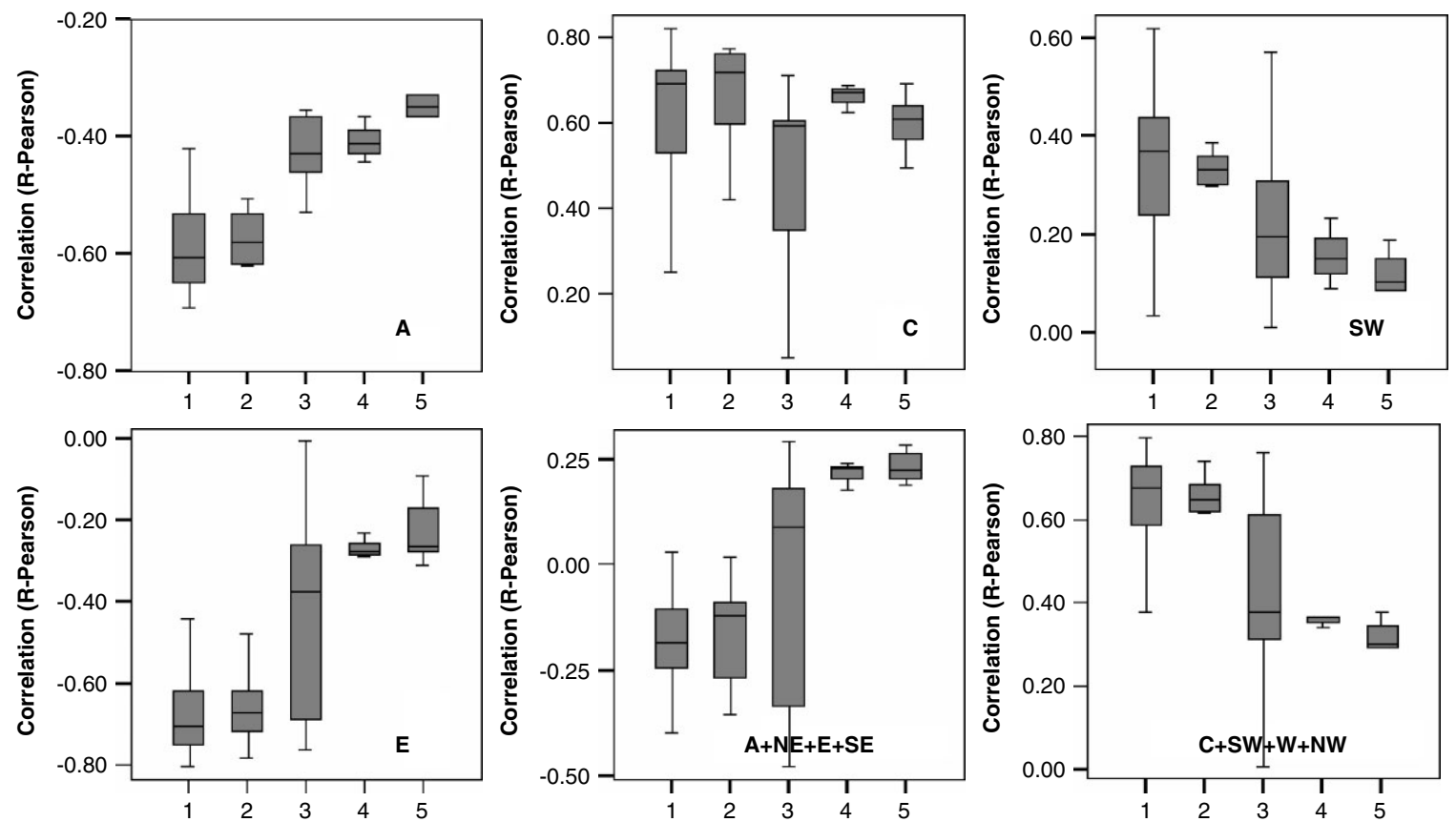

Figure 11. Box-plot of correlation values between weather-type frequency and winter SPI as a function of observatories with negative, positive and non-significant trends in winter SPI values. 1, Negative and significant trend $(\alpha<0.01)$; 2, Negative and significant trend $(\alpha<0.05) ; 3$, Non-significant trend; 4, Positive and significant trend $(\alpha<0.05) ; 5$, Positive and significant trend $(\alpha<0.01)$

Table V. Correlation between the winter teleconnection indices and the frequency of the different weather types

\begin{tabular}{lcccc}
\hline & NAO & EA & EAWR & SCA \\
\hline A & $0.84^{\mathrm{a}}$ & $0.38^{\mathrm{a}}$ & 0.22 & $-0.41^{\mathrm{a}}$ \\
$\mathrm{C}$ & $-0.76^{\mathrm{a}}$ & -0.25 & -0.15 & $0.34^{\mathrm{b}}$ \\
$\mathrm{N}$ & -0.05 & -0.25 & -0.07 & -0.11 \\
NE & 0.16 & -0.24 & -0.04 & -0.18 \\
$\mathrm{E}$ & 0.06 & $-0.43^{\mathrm{a}}$ & $0.36^{\mathrm{a}}$ & -0.28 \\
SE & -0.05 & $-0.32^{\mathrm{b}}$ & $0.47^{\mathrm{a}}$ & -0.01 \\
S & -0.15 & -0.06 & 0.20 & 0.12 \\
SW & $-0.40^{\mathrm{a}}$ & 0.23 & $-0.29^{\mathrm{b}}$ & $0.29^{\mathrm{b}}$ \\
W & $-0.39^{\mathrm{a}}$ & 0.25 & $-0.48^{\mathrm{a}}$ & $0.34^{\mathrm{b}}$ \\
NW & -0.05 & 0.12 & $-0.34^{\mathrm{b}}$ & $0.29^{\mathrm{b}}$ \\
A + NE + E + SE & $0.77^{\mathrm{a}}$ & 0.03 & $0.44^{\mathrm{a}}$ & $-0.48^{\mathrm{a}}$ \\
$\mathrm{C}+\mathrm{SW}+\mathrm{W}+\mathrm{NW}$ & $-0.74^{\mathrm{a}}$ & 0.07 & $-0.47^{\mathrm{a}}$ & $0.51^{\mathrm{a}}$ \\
$\mathrm{C}+\mathrm{E}+\mathrm{SE}+\mathrm{S}$ & $-0.54^{\mathrm{a}}$ & $-0.46^{\mathrm{a}}$ & 0.27 & 0.16 \\
\hline
\end{tabular}

${ }^{\text {a }}$ Significant correlation $(\alpha<0.01)$.

${ }^{\mathrm{b}}$ Significant correlation $(\alpha<0.05)$. 


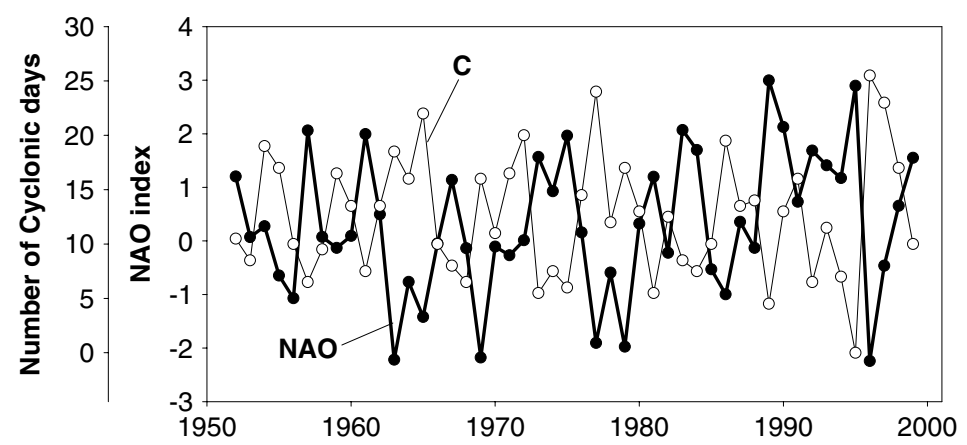

Figure 12. Evolution of the winter NAO index and the frequency of winter cyclonic (C) days (1952-1999)
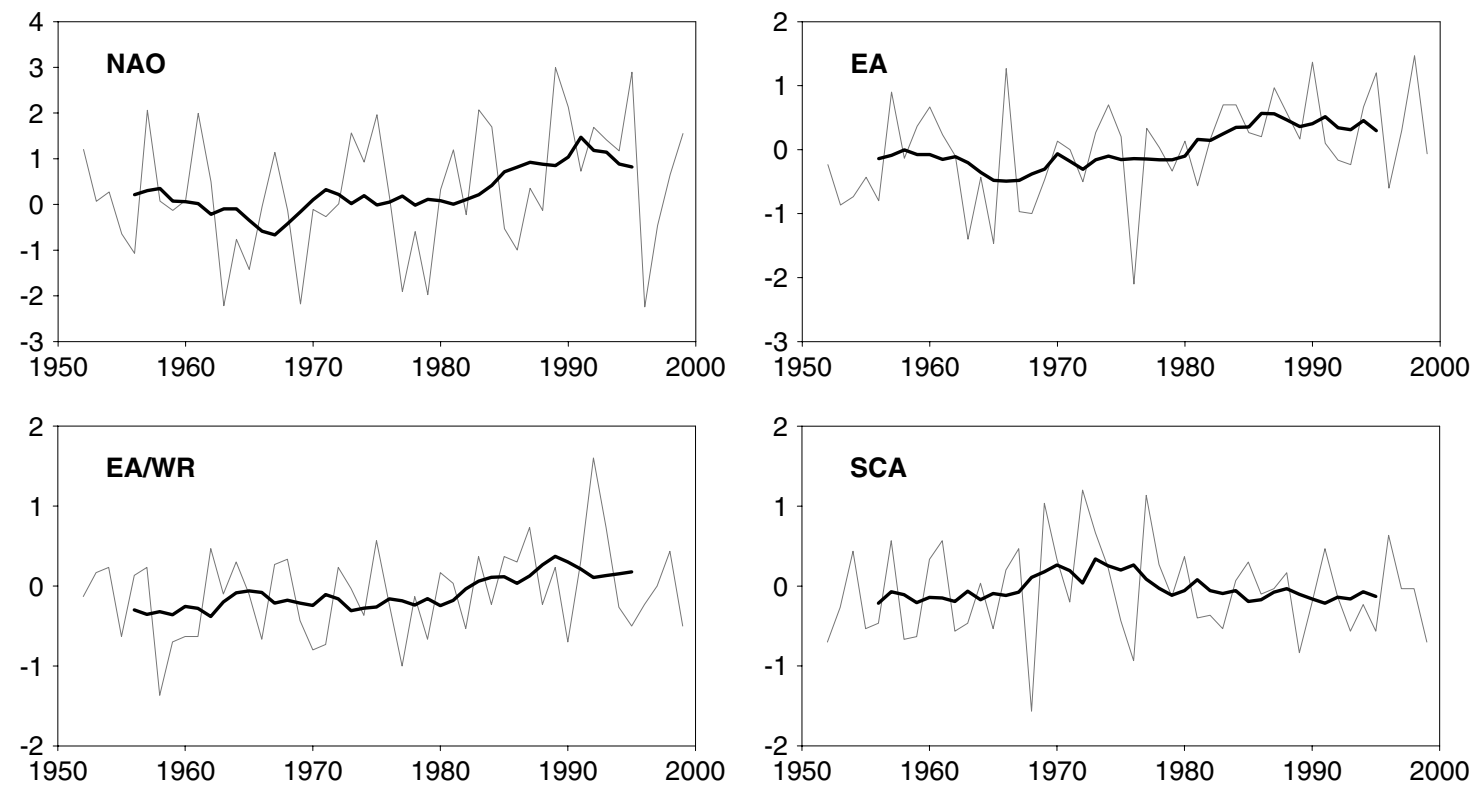

Figure 13. Evolution of the different teleconnection indices. Black line indicates the 9-year moving average. 1952-1999

The evolution of the four atmospheric circulation patterns is shown in Figure 13. The NAO index shows a positive and significant trend $(R h o=0.67, \alpha<0.01)$, the same as the EA $(R h o=0.67, \alpha<0.01)$, and the EA/WR pattern $(R h o=0.82, \alpha<0.01)$. The SCA pattern does not show a significant trend.

Thus, the variability of the general atmospheric circulation modes in the Northern Hemisphere greatly determines the temporal variability of the different weather types, mainly the NAO. Moreover, the trends observed in the frequencies of different weather types agree with the trends observed in the Atmospheric circulation patterns. Positive trends of Anticyclonic weather types and negative trends in cyclonic types are related to the increase in the NAO index during the second half of the twentieth century. The decrease in the frequency of the SW and W weather types is also related to the NAO evolution.

The NAO shows persistent positive and negative phases of several years duration (Hurrell, 1995). A clear dominance of positive values has occurred since the 1980s. Winters with positive NAO values show an increase of zonal flows (Hurrell, 1995) and dry conditions are usually recorded in the Iberian Peninsula (Hurrell and Van Loon, 1997; Trigo et al., 2004), which is associated with an increase in the frequency of anticyclonic days. In the Iberian Peninsula, Corte-Real et al. (1998) indicated that the reduction of weather types prone to precipitation since 1960 was greatly related to changes in the NAO intensity. 
Nevertheless, although NAO has the highest importance in explaining the temporal patterns in the frequency of the weather types, the increase of the east types and decrease of the west types were also related to the positive trend of the EA/WR pattern, whose positive phase shows high pressures on the British Isles and low pressures west of the Iberian Peninsula, generating dominant flows from the east.

\subsection{Influence of the general atmospheric circulation patterns on winter droughts}

Finally, we analysed the role of the general atmospheric circulation patterns on the spatial and temporal variability of winter droughts in the study area. Table VI shows the correlation between the teleconnection indices and the four drought components obtained from PCA. Significant correlations were found only between the series of components 1 (north) and 2 (centre of the Ebro Valley) and the NAO and between the series of component 1 and the EA/WR pattern. Component 3 does not show significant correlations with any atmospheric circulation pattern.

The spatial distribution of correlations is shown in Figure 14. There are general negative correlations between the NAO index and the SPI values in the whole of the study area, although correlations are higher in the centre of the Ebro Valley $(r<-0.6)$, whereas correlations are not significant in the south. The correlations

Table VI. Correlation between the series of each component and the time series of the winter atmospheric circulation patterns

\begin{tabular}{llrcc}
\hline Components & NAO & EA & EA/WR & SCA \\
\hline Component 1 & $-0.47^{\mathrm{a}}$ & 0.14 & $-0.54^{\mathrm{a}}$ & 0.17 \\
Component 2 & $-0.47^{\mathrm{a}}$ & -0.18 & -0.04 & 0.16 \\
Component 3 & -0.17 & -0.03 & 0.07 & 0.12 \\
Component 4 & -0.26 & -0.18 & -0.16 & 0.15
\end{tabular}

${ }^{\text {a }}$ Significant correlation $(\alpha<0.01)$.
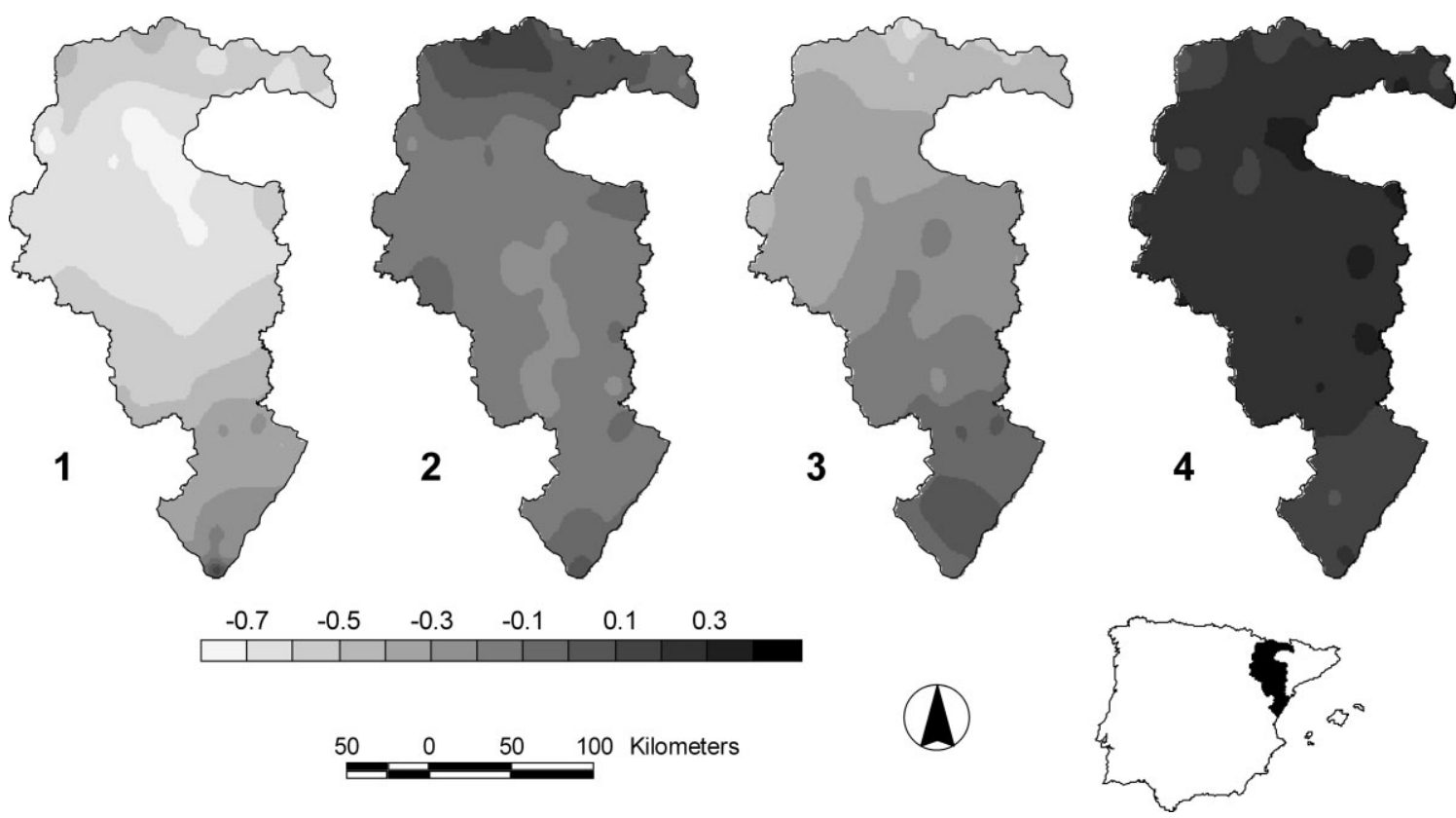

Figure 14. Spatial distribution of correlation between winter SPI and the general winter atmospheric circulation patterns. 1, NAO; 2 , EA; 3, EA/WR; 4, SCA. Significant correlations correspond to $R$ values higher than 0.29 or lower than $-0.29(\alpha<0.05)$ 


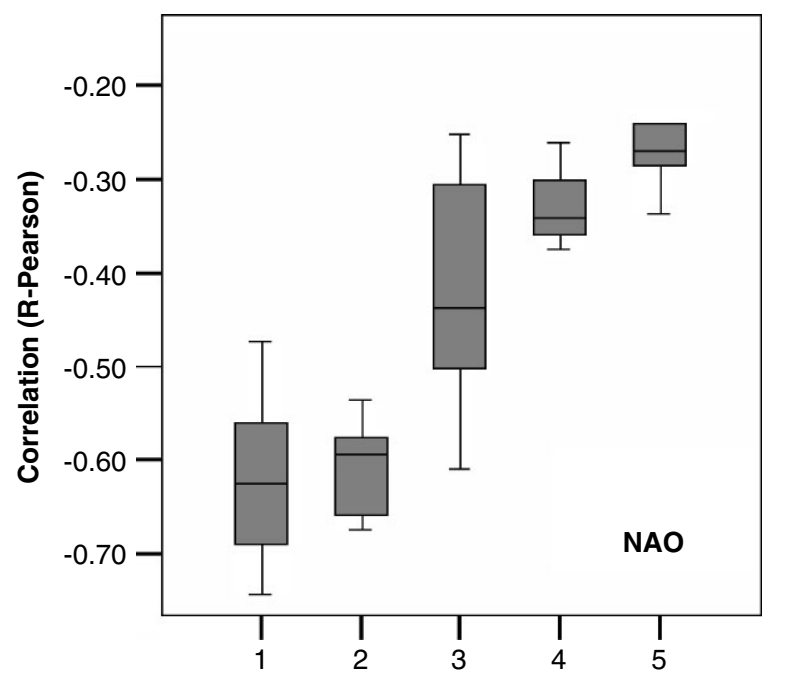

Figure 15. Box-plot of correlation values between the NAO and the winter SPI as a function of observatories with negative, positive and non-significant trends in winter-SPI values. 1, Negative and significant trend $(\alpha<0.01) ; 2$, Negative and significant trend $(\alpha<0.05)$; 3, Non-significant trend; 4, Positive and significant trend $(\alpha<0.05) ; 5$, Positive and significant trend $(\alpha<0.01)$

with the EA and SCA patterns are lower, and negative and significant correlations were also obtained only in the north of the study area between the winter SPI and the EA/WR pattern.

The correlations between the teleconnection indices and the winter-SPI series are lower than the correlations obtained between SPI and the frequency of the different weather types. Moreover, only in the centre and north of the study area is the role of the general atmospheric circulation patterns on winter droughts well identified.

Differences in the correlations between the atmospheric circulation patterns and the SPI as a function of trends in SPI values were also identified for the NAO. Figure 15 shows the distribution of the $R$ values between the winter NAO and the SPI in each observatory as a function of trends in the winter SPI. The areas with negative and significant trends show the highest average correlations between the SPI and the NAO (average $R=-0.62$ ), whereas the areas with positive trends do not show significant correlations with the NAO index (average $R=-0.26$ ).

\section{CONCLUSIONS}

This paper has analysed the influence of the atmospheric circulation at different spatial scales on spatial and temporal patterns of winter droughts in a semi-arid north-south gradient in Northeast Spain. We obtained a daily weather-type classification for the whole of the Iberian Peninsula during the winter season, finding a general positive trend in the frequency of the weather types prone to dry conditions (A, SE and E) and a general negative trend of cyclonic and west weather types (SW, W and NW).

We analysed the winter droughts in the study area by means of the SPI, considering a high density of observatories (75). Winter droughts show an important spatial variability, and the temporal evolution of droughts within the study area was very different between regions, differentiating three well-defined patterns corresponding to the north, the centre of the Ebro Valley, and the Mediterranean coastland. The evolution indicates a general negative trend in the SPI values, indicative of drier conditions between 1952 and 1999, and this also agrees with the evolution in the Iberian Peninsula and in other Mediterranean regions as a consequence of the persistence of dry winters during the decades of 1980 and 1990 (Hisdal et al., 2001; Szinell et al., 1998; Brunetti et al., 2001; Esteban-Parra et al., 1998). Nevertheless, the study area also recorded important spatial differences: negative trends were identified in the north and centre of the study area, whereas trends were positive in the Mediterranean coastland. 
These results indicate that although some studies on droughts have been performed on a continental scale (Briffa et al., 1994; Lloyd-Hughes and Saunders, 2002b), in areas under Mediterranean climate conditions, model outputs are not the best approach for sub-regional management of droughts, which are highly variable in space. The spatial differences in the weather-type influence on droughts have been identified through the use of a dense net of observatories, which confirms the need for using dense databases for climatological studies in areas of high spatial precipitation variability (Houghton et al., 2001).

In general, very clear spatial gradients in the influence of the different weather types was shown between the north and south regions or between the centre of the Ebro Valley, the Pyrenean range, and the Mediterranean coastland. The weather-type frequency that most affects winter drought conditions differs greatly between areas.

Significant negative and positive correlation between the respective frequency of anticyclonic and cyclonic weather types and the winter-SPI series were found in the whole of the study area. Nevertheless, correlations are higher in the centre of the Ebro Valley than in the north or the Mediterranean coastland. In the Pyrenean mountains, correlations are higher considering the sum of the frequency of cyclonic and directional weather types of the west, $\mathrm{W}+\mathrm{SW}+\mathrm{NW}$, whereas in the south the correlations are higher considering the cyclonic and the east weather types, $\mathrm{E}+\mathrm{SE}+\mathrm{S}$. When the directional weather types are considered independently, only the west weather types $(\mathrm{W}+\mathrm{SW}+\mathrm{NW})$ show significant correlations with the winter SPI in the northern region.

Although air temperature and atmospheric humidity, which can be determinants to better explain the role of weather types on precipitation (Goodess and Jones, 2002; Maheras et al., 2004), were not considered in this research, an important percentage of the interannual variability of winter SPI and its spatial differences in the study area are well explained by means of the frequency of only a few weather types.

The general negative trends in winter-SPI values agree with the decrease in the frequency of weather types prone to cause precipitation, such as the $\mathrm{C}, \mathrm{SW}$ and $\mathrm{W}$ weather types, and the increase in the frequency of A weather types. This was observed in the areas where precipitation is most affected by the $\mathrm{C}, \mathrm{SW}$ and $\mathrm{W}$ weather types, where an increase in droughts was the general pattern between 1952 and 1999. Nevertheless, in the Mediterranean coastland the positive trend in SPI values agrees with the increase in the frequency of weather types of the east (E, SE), which are prone to cause precipitation in this area.

The interannual variations in the frequency of the different weather types were greatly determined by different general atmospheric circulation patterns, mainly the NAO. Moreover, the NAO significantly affects the SPI spatial and temporal variability in the study area. This suggests that the use of weather-type classifications and time series of weather-type frequency to explain the winter drought variability could be substituted by a few atmospheric indices that summarise the general atmospheric circulation in Northern Europe. Nevertheless, in this paper we have shown that although the NAO strongly determines the frequency of different weather types, correlations between weather-type frequency series and the winter SPI is higher than correlations found between SPI and NAO. Moreover, spatial differences and gradients found in the influence of weather types on droughts coincide with the general spatial patterns of SPI series. This suggests that differences in the winter-SPI evolution were greatly determined by spatial differences in the weathertype influence. We must also take into account that in some areas, such as the Mediterranean coastland, the interannual variability of winter droughts are not well explained by the general atmospheric circulation patterns, while the frequency of some weather types strongly affects the drought conditions.

Thus, although the interannual variability of the NAO explains an important percentage of the interannual differences in weather-type frequency, this general atmospheric circulation index is insufficient to explain the spatial and temporal variability of droughts in the study area, since these droughts respond better to the atmospheric variability at more detailed (synoptic) spatial scales.

\section{ACKNOWLEDGEMENTS}

This work has been supported by the projects: 'Caracterización espacio-temporal de las sequías en el valle medio del Ebro e identificación de sus impactos' (BSO2002-02743), 'Variabilidad climática y dinámica forestal en ecosistemas de ecotono' (REN2003-07453), Procesos hidrológicos y erosivos en cuencas pirenaicas 
en relación a cambios de usos de suelo y variabilidad climática (PIRIHEROS, REN2003-08678/HID) 'Caracterización y modelización de procesos hidrológicos en cuencas aforadas para predicción en cuencas no aforadas' (CANOA, CGL 2004-04919-c02-01), all funded by the Spanish Commission of Science and Technology (CICYT) and FEDER, and 'Programa de grupos de investigación consolidados' (grupo Clima, Cambio Global y Sistemas Naturales, BOA 48 of 20-04-2005), financed by the Aragón Government. We want to thank to the National Institute of Meteorology (INM) for providing the data used in this work. Research of the second author was supported by postdoctoral fellowships by the Ministerio de Educación, Cultura y Deporte (Spain).

\section{REFERENCES}

Alexandersson H. 1986. A homogeneity test applied to precipitation data. Journal of Climatology 6: 661-675.

Alexandersson H, Moberg A. 1997. Homogenization of Swedish temperature data. Part I: homogeneity test for lineal trends. International Journal of Climatology 17: 25-34.

Amanatidis GT, Paliatsos AG, Depapis CC. 1993. Decreasing precipitation trend in the Marathon area, Greece. International Journal of Climatology 13: 191-201.

Austin RB, Cantero-Martínez C, Arrúe JL, Playán E, Cano-Marcellán P. 1998. Yield-rainfall relationships in cereal cropping systems in the Ebro river valley of Spain. European Journal of Agronomy 8: 239-248.

Barnston AG, Livezey RE. 1987. Classification, seasonality and persistence of low-frequency atmospheric circulation patterns. Monthly Weather Review 115: 1083-1126.

Basnett TA, Parker DE. 1997. Development of the Global Mean Sea Level Pressure Data Set GMSLP2, Climate Research Technical Note 79. Hadley Centre, Meteorological office: Bracknell.

Beran MA, Rodier JA. 1985. Hydrological Aspects of Drought, Studies and Reports in Hydrology, 39. UNESCO - WMO: Geneve.

Bonaccorso B, Bordi I, Cancielliere A, Rossi G, Sutera A. 2003. Spatial variability of drought: an analysis of the SPI in Sicily. Water Resources Management 17: 273-296.

Bordi I, Fraedrich FW, Gerstengarbe FW, Werner C, Sutera A. 2004. Spatio-temporal variability of dry and wet periods in eastern China. Theoretical and Applied Climatology 77: 125-138.

Briffa KR, Jones PD, Hulme M. 1994. Summer moisture variability across Europe, 1892-1991: an analysis based on the Palmer drought severity index. International Journal of Climatology 14: 475-506.

Brunetti M, Mangueri M, Nanni T. 2001. Changes in total precipitation, rainy days and extreme events in northeastern Italy. International Journal of Climatology 21: 861-871.

Brunetti M, Mangeri M, Nanni T. 2002. Atmospheric circulation and precipitation in Italy for the last 50 years. International Journal of Climatology 22: 1455-1471.

Brunetti M, Buffoni L, Mangeri M, Nanni T. 2000. Precipitation intensity trends in northern Italy. International Journal of Climatology 20: $1017-1031$

Camarasa A. 1993. La estructura interna de las tormentas mediterráneas. Cuadernos de Geografía 54: 169-188.

Capel JJ. 2000. El clima de la Península Ibérica. Ariel: Barcelona.

Cordery I, McCall M. 2000. A model for forecasting drought from teleconnections. Water Resources Research 36: $763-768$.

Corte-Real J, Qian B, Xu H. 1998. Regional climate change in Portugal: precipitation variability associated with large-scale atmospheric circulation. International Journal of Climatology 18: 619-635.

Creus J. 1983. El clima del alto Aragón Occidental, Monografías del Instituto de Estudios Pirenaicos, 109. Instituto de Estudios Pirenaicos: Jaca; 233.

Creus J, Ferraz J. 1995. Irregularidad pluviométrica y continentalidad térmica en el valle medio del Ebro. Lucas Mallada 7: 147-164.

Crisciani F, Ferraro S, Riicich F. 1994. Evidence of recent climatic anomalies at Trieste (Italy). Climatic Change 28: 365-374.

Cuadrat JM. 1999. El clima de Aragón, Caja de Ahorros de la Inmaculada: Zaragoza; 109.

Delitala AMS, Cesari D, Chessa PA, Ward MN. 2000. Precipitation over Sardinia (Italy) during the 1946-1993 rainy season and associated large-scales climate variations. International Journal of Climatology 20: 519-541.

De Luis M, Raventós J, González-Hidalgo JC, Sánchez JR, Cortina J. 2000. Spatial analysis of rainfall trends in the region of Valencia (East Spain). International Journal of Climatology 20: 1451-1469.

Deser C, Blackmon ML. 1993. Surface climate variations over North Atlantic Ocean during winter: 1900-1989. Journal of Climate 6: $1743-1753$.

Domonkos P. 2003. Recent precipitation trends in Hungary in the context of larger scale climatic changes. Natural Hazards 29: $255-271$.

Dünkeloh A, Jacobeit J. 2003. Circulation dynamics of Mediterranean precipitation variability 1948-98. International Journal of Climatology 23: 1843-1866.

Eder BK, Davis JM, Monahan JF. 1987. Spatial and temporal analysis of the Palmer drought severity index over the south-eastern united States. Journal of Climatology 7: 31-51.

Edwards DC, McKee TB. 1997. Characteristics of $20^{\text {th }}$ Century Drought in the United States at Multiple Time Scales, Atmospheric Science Paper No. 634. Colorado State University, Fort Collins, Colorado.

Esteban-Parra MJ, Rodrigo FS, Castro-Díez Y. 1998. Spatial and temporal patterns of precipitation in Spain for the period $1880-1992$. International Journal of Climatology 18: 1557-1574.

Esteban P, Jones PD, Martín-Vide J, Mases M. 2005. Atmospheric circulation patterns related to heavy snowfall days in Andorra, Pyrenees. International Journal of Climatology 25: 319-329.

Estrela MJ, Peñarrocha D, Millán M. 2000. Multi-annual drought episodes in the mediterranean (Valencia region) from 1950-1996. A spatio-temporal analysis. International Journal of Climatology 20: 1599-1618. 
Feldstein SB. 2000. The timescale, power spectra, and climate noise properties of teleconnection patterns. Journal of Climate 13: 4430-4440.

Fernández-Mills G. 1995. Principal component analysis of precipitation and rainfall regionalization in Spain. Theoretical and Applied Climatology 50: 169-183.

Flohn H, Kapala A, Knoche MR, Mächel H. 1993. Water vapour as amplifier of the greenhouse effect: new aspects. Meteorologische Zeitschrift 1: 122-138.

Fowler HJ, Kilsby CG. 2002. A weather-type approach to analysing water resource drought in the Yorkshire region from 1881-1998. Journal of Hydrology 262: 177-192.

Fraedrich K. 1994. An ENSO impact on Europe? Tellus 46A: 541-552.

González-Hidalgo JC, De Luis M, Stepanek P, Raventós J, Cuadrat JM. 2002. Reconstrucción, estabilidad y procesos de homogeneizado de series de precipitación en ambientes de elevada variabilidad pluvial. In La Información Climática Como Herramienta De Gestión Ambiental, Cuadrat JM, Vicente SM, y Saz MA (eds). Universidad de Zaragoza: Zaragoza; 47-57.

González-Rouco JF, Heyen H, Zorita E, Valero F. 2000. Agreement between observed rainfall trends and climate change simulations in the south west of Europe. Journal of Climate 13: 3057-3065.

González-Rouco JF, Jiménez JL, Quesada V, Valero F. 2001. Quality control and homogeneity of precipitation data in the Southwest of Europe. Journal of Climate 14: 964-978.

Goodess C. 2000. The construction of daily rainfall scenarios for Mediterranean sites using a circulation type approach to downscaling, $\mathrm{PhD}$ thesis, University of East Anglia.

Goodess C, Palutikof JP. 1998. Development of daily rainfall scenarios for southeast Spain using a circulation-type approach to downscaling. International Journal of Climatology 18: 1051-1083.

Goodess CM, Jones PD. 2002. Links between circulation and changes in the characteristics of Iberian rainfall. International Journal of Climatology 22: 1593-1615.

Guttman NB. 1998. Comparing the Palmer drought index and the Standardized Precipitation Index. Journal of the American Water Resources Association 34: 113-121.

Guttman NB. 1999. Accepting the standardized precipitation index: a calculation algorithm. Journal of the American Water Resources Association 35: 311-322.

Hayes M, Wilhite DA, Svoboda M, Vanyarkho O. 1999. Monitoring the 1996 drought using the Standardized Precipitation Index. Bulletin of the American Meteorological Society 80: 429-438.

Hisdal H, Stahl K, Tallaksen LM, Demuth S. 2001. Have streamflow droughts in Europe become more severe or frequent? International Journal of Climatology 21: 317-333.

Hosking JRM. 1990. L-Moments: analysis and estimation of distributions using linear combinations of order statistics. Journal of the Royal Statistical Society Series B 52: 105-124.

Houghton JT, Ding Y, Giggs D, Noguet M, van del Linden P, Dai X, Maskell A, Johnson CA. 2001. Climate Change 2001: The scientific Basis. Cambridge University Press: Cambridge.

Hulme M, Briffa KR, Jones PD, Senior CA. 1993. Validation of GCM control simulations using indices of daily airflow types over British Isles. Climate Dynamics 9: 95-105.

Hurrell J. 1995. Decadal trends in North Atlantic Oscillation and relationship to regional temperature and precipitation. Science 269: $676-679$.

Hurrell J, Van Loon H. 1997. Decadal variations in climate associated with the North Atlantic Oscillation. Climatic Change 36: $301-326$.

Jenkinson AF, Collison P. 1977. An Initial Climatology of Gales Over the North Sea, Synoptic Climatology Branch Memorandum, 62. Meteorological Office: Londres; 18.

Jones PD, Hulme M, Briffa KR. 1993. A comparison of Lamb circulation types with an objective classification scheme. International Journal of Climatology 13: 655-663.

Jones PD, Jónsson T, Wheeler D. 1997. Extension to the North Atlantic Oscillation using early instrumental pressure observations from Gibraltar and South-West Iceland. International Journal of Climatology 17: 1433-1450.

Jones PD, Moberg A. 2003. Hemispheric and large-scale surface air temperature variations: an extensive revision and an update to 2001. Journal of Climate 16: 206-223.

Kahana R, Ziv B, Enzel Y, Dayan U. 2002. Synoptic climatology of major floods in the Negev desert, Israel. International Journal of Climatology 22: 867-882.

Kahana R, Ziv B, Dayan U, Enzel Y. 2004. Atmospheric predictors for major floods in the Negev desert, Israel. International Journal of Climatology 24: 1137-1147.

Karl TR, Koscielny AJ. 1982. Drought in the United States: 1895-1981. Journal of Climatology 2: 313-329.

Keiser DT, Griffiths JF. 1997. Problems associated with homogeneity testing in climate variations studies: a case study of temperature in the Northern Great Plains, USA. International Journal of Climatology 17: 497-510.

Keyantash J, Dracup J. 2002. The quantification of drought: an evaluation of drought indices. Bulletin of the American Meteorological Society 83: $1167-1180$.

Krichak SO, Alpert P. 2005. Decadal trends in the east Atlantic-west Russia pattern and Mediterranean precipitation. International Journal of Climatology 25: 183-192.

Kutzbach JE. 1970. Large-scale features of monthly mean northern hemisphere maps of sea level pressure. Monthly Weather Review 98: $708-721$.

Labajo JL, Piorno A, Izquierdo MJ. 1998. Temporal behaviour of the annual mean pressure on the northern Spanish plateau between 1945 and 1994. International Journal of Climatology 18: 637-647.

Lamb HH. 1972. British Isles Weather Types and a Register of Daily Sequence of Circulation Patterns, 1861-1971, Geophysical Memoir, 116. HMSO: London; 85.

Lana X, Serra C, Burgueño A. 2001. Patterns of monthly rainfall shortage and excess in terms of the Standardised Precipitation Index for Catalonia (NE Spain). International Journal of Climatology 21: 1669-1691.

Lanzante JR. 1996. Resistant, robust and non-parametric techniques for the analysis of climate data: theory and examples, including applications to historical radiosonde station data. International Journal of Climatology 16: 1197-1226. 
Linderson M. 2001. Objective classification of atmospheric circulation over southern Scandinavia. International Journal of Climatology 21: $155-169$.

Linés A. 1981. Perturbaciones Típicas que Afectan a la Península Ibérica y Precipitaciones Asociadas. INM: Madrid.

Lloyd-Hughes B, Saunders MA. 2002a. Seasonal prediction of european spring precipitation from El Niño-southern oscillation and local sea-surface temperatures. International Journal of Climatology 22: 1-14.

Lloyd-Hughes B, Saunders MA. 2002b. A drought climatology for Europe. International Journal of Climatology 22: 1571-1592.

López Bermúdez F. 1985. Sequía, Aridez y Desertificación en Murcia. Discurso de ingreso en la Academia Alfonso X el Sabio: Murcia; 85.

López Bermúdez F, Alonso F. 2001. Aridez y sequías en la cuenca del Segura. In Causas y Consecuencias de las Sequías en España, Gil A, y Morales A (eds). CAM: Alicante; 187-206.

López Moreno JI, Beguería S, García Ruiz JM. 2002. Influence of the Yesa reservoir on floods of the Aragón River, central Spanish Pyrenees. Hydrology and Earth System Sciences 6: 753-762.

López Moreno JI, García Ruiz JM. 2004. Influence of snow accumulation and snowmelt on streamflow in the Central Spanish Pyrenees. International Journal of Hydrological Sciences 49: 787-802.

López Moreno JI. 2005. Recent variations of snowpack depth in the Central Spanish Pyrenees. Arctic Antarctic and Alpine Research 37: $253-260$.

López Moreno JI, Beguería S, García-Ruiz JM. 2005. The management of a large Mediterranean reservoir: storage regimes of the Yesa reservoir, Upper Aragón River basin, Central Spanish Pyrenees. Environmental Management 34: 508-515.

Loukas A, Vasiliades L. 2004. Probabilistic analysis of drought spatiotemporal characteristics in Thessaly region, Greece. Natural Hazards and Earth System Sciences 4: 719-731.

Maheras P. 1988. Changes in precipitation conditions in the Western Mediterranean over the last century. Journal of Climatology 8: $179-189$.

Maheras P, Kolyva-Machera F. 1990. Temporal and spatial characteristics of annual precipitation over the Balkans in the twentieth century. International Journal of Climatology 10: 495-504.

Maheras P, Patrikas I, Karacostas T, Anagnostopoulou C. 2000. Automatic classification of circulation types in Greece: methodology, description, frequency, variability and trend analysis. Theoretical and Applied Climatology 67: 205-223.

Maheras P, Tolika K, Anagnostopoulou C, Vafiadis M, Patrikas I, Flocas H. 2004. On the relationships between circulation types and changes in rainfall variability in Greece. International Journal of Climatology 24: 1695-1712.

Marshall J, Kushnir Y, Battisti D, Chang P, Czaja A, Dickson R, McCartney M, Saravanan R, Visbek M. 2001. North Atlantic climate variability: phenomena, impacts and mechanisms. International Journal of Climatology 21: 1863-1898.

Martín-Vide J. 2002. Aplicación de la clasificación sinóptica automática de Jenkinson y Collison a días de precipitación torrencial en el este de España. In La información Climática Como Herramienta de Gestión Ambiental, Cuadrat JM, Vicente SM, y Saz MA (eds). Universidad de Zaragoza: Zaragoza; 123-127.

Martín-Vide J, Fernández D. 2001. El índice NAO y la precipitación mensual en la España peninsular. Investigaciones Geográficas 26: 41-58.

Martín-Vide J, Llasat MC. 2000. Las precipitaciones torrenciales en Cataluña. Series Geográfica 9: 17-26.

Matyasovszky I, Bogardi I, Bardossy A, Duckstein L. 1993. Estimation of local precipitation statistics reflecting climate change. Water Resources Research 29: 3955-3968.

McCabe GJ, Muller RA. 2002. Effects of ENSO on weather-type frequencies and properties at New Orleans Louisiana, USA. Climate Research 20: 95-105.

McKee TBN, Doesken J, Kleist J. 1993. The relationship of drought frequency and duration to time scales. Eight Conference. On Applied Climatology. American Meteorological Society: Anaheim, CA; 179-184.

McKee TBN, Doesken J, Kleist J. 1995. Drought monitoring with multiple time scales. Ninth Conference On Applied Climatology. American Meteorological Society: Dallas, TX; 233-236.

Millán M, Estrela MJ, Caselles V. 1995. Torrential precipitations on the Spanish east coast: the role of the Mediterranean sea surface temperature. Atmospheric Research 36: 1-16.

Min SK, Kwon WT, Park EH, Choi Y. 2003. Spatial and temporal comparisons of droughts over Korea with East Asia. International Journal of Climatology 23: 223-233.

Mitasova H, Mitas L. 1993. Interpolation by regularized Spline with Tension. Mathematical Geology 25: 641-655.

Moberg A, Bergstrom H. 1997. Homogenization of Swedish temperature data. Part III: the long temperature records from Uppsala and Stockholm. International Journal of Climatology 17: 667-699.

Molinero F. 2001. Consecuencias agrarias de las sequías en Castilla y León. In Causas y Consecuencias de las Sequías en España, Gil Olcina y A, Morales Gil A (eds). Universidad de Alicante: Alicante; 261-276.

Morales A, Olcina J, Rico AM. 2000. Diferentes persepciones de la sequía en España: adaptación, catastrofismo e intentos de corrección. Investigaciones Geográficas 23: 5-46.

Ntale HK, Gan T. 2003. Drought indices and their application to East Africa. International Journal of Climatology 23: $1335-1357$.

Oladipo EO. 1986. Spatial patterns of drought in the interior plains of North America. Journal of Climatology 6: $495-513$.

Olcina J. 2001. Tipología de sequías en España. Ería 56: 201-227.

Palmer WC. 1965. Meteorological Droughts, U.S. Department of Commerce Weather Bureau Research Paper 45, Washington DC; 58. Pausas JG. 2004. Changes in fire and climate in the eastern Iberian Peninsula (Mediterranean basin). Climatic Change 63: 337-350.

Pedrocchi C. 1998. Ecología de los Monegros. Instituto de Estudios Altoaragoneses; 430.

Pérez-Cueva AJ. 1994. Atlas Climàtic de la Comunitat Valenciana. Generalitat Valenciana: Valencia; 205.

Pesti G, Shrestha BP, Duckstein L, Bogárdi I. 1996. A fuzzy rule-based approach to drought assessment. Water Resources Research 32: $1741-1747$.

Peterson TC, Easterling DR. 1994. Creation of homogeneous composite climatological reference series. International Journal of Climatology 14: 671-679. 
Peterson TC, Easterling DR, Karl TR, Groisman P, Nicholls N, Plummer N, Torok S, Auer I, Boehm R, Gullett D, Vincent L, Heino R, Tuomenvirta H, Mestre O, Szentimrey T, Salinger J, Forland EJ, Hanssen-Bauer I, Alexandersson H, Jones P, Parker O. 1998. Homogeneity adjustments of in situ atmospheric climate data: a review. International Journal of Climatology 18: $1493-1517$.

Phillips ID, McGregor GR. 2001. The relationship between synoptic scale airflow direction and daily rainfall: a methodology applied to Devon and Cornwall, South Walles England. Theoretical and Applied Climatology 69: 179-198.

Piervitali E, Colacino M, Conte M. 1997. Signals of climatic change in the central-western Mediterranean basin. Theoretical and Applied Climatology 58: 211-219.

Pita MF. 2001. Sequías en la cuenca del Guadalquivir. In Causas y Consecuencias de las Sequías en España, Gil A, y Morales A (eds). CAM: Alicante; 303-344.

Pozo-Vázquez D, Esteban-Parra MJ, Rodrigo FS, Castro-Díez Y. 2001. The association between ENSO and winter atmospheric circulation and temperature in the north Atlantic region. Journal of Climate 14: 3408-3420.

Pozo-Vázquez D, Gámiz-Fortis SR, Tovar-Pescador J, Esteban-Parra MJ, Castro-Díez Y. 2004. El Niño-Southern oscillation events and associated European winter precipitation anomalies. International Journal of Climatology 25: 17-31.

Rasilla D. 2002. Aplicación de un método de clasificación sinóptica a la Península Ibérica. Investigaciones Geográficas 30: $27-45$.

Rasilla D, García-Codrón JC, Garmendia C. 2002. Los temporales de viento: propuesta metodológica para el análisis de un fenómeno infravalorado. In La Información Climática Como Herramienta de Gestión Ambiental, Cuadrat JM, Vicente SM, y Saz MA (eds). Universidad de Zaragoza: Zaragoza; 129-136.

Richman MB. 1986. Rotation of principal components. Journal of Climatology 6: 29-35.

Rodó X, Baert E, Comín FA. 1997. Variations in seasonal rainfall in southern Europe during the present century: relationships with the North Atlantic Oscillation and the El Niño-Southern oscillation. Climate Dynamics 13: 275-284.

Rodríguez R, Llasat MC, Wheeler D. 1999. Analysis of the Barcelona precipitation series, 1850-1991. International Journal of Climatology 19: 787-801.

Rodríguez-Puebla C, Encinas AH, Nieto S, Garmendia J. 1998. Spatial and temporal patterns of annual precipitation variability over the Iberian Peninsula. International Journal of Climatology 18: 299-316.

Romero R, Summer G, Ramis C, Genovés A. 1999. A classification of the atmospheric circulation patterns producing significant daily rainfall in the Spanish Mediterranean area. International Journal of Climatology 19: 765-785.

Rouault M, Richard Y. 2003. Intensity and spatial extension of droughts in South Africa at different time scales. Water SA 29: 489-500.

Ruiz E. 1982. La transición climática del Cantábrico Oriental al valle medio del Ebro. Diputación Foral de Álava: Vitoria; 651.

Salinger MJ, Basber RE, Fitzbarris BB, Hay JE, Jones PD, Maceight JP, Schmidely-Leleu I. 1995. Climatic trends in the south-west pacific. International Journal of Climatology 15: 285-302.

Sankarasubramanian A, Srinivasan K. 1999. Investigation and comparison of sampling properties of L-moments and conventional moments. Journal of Hydrology 218: 13-34.

Santos JA, Corte-Real J, Leite SM. 2005. Weather regime and their connection to the winter rainfall in Portugal. International Journal of Climatology 25: 33-50.

Serra C, Fernández Mills G, Periago MC, Lana X. 1996. Winter and autumn daily precipitation patterns in catalonia, Spain. Theoretical and Applied Climatology 54: 175-186.

Serrano A, García JA, Mateos VL, Cancillo ML, Garrido J. 1999. Monthly modes of variation of precipitation over the Iberian Peninsula. Journal of Climate 12: 2894-2919.

Sheridan SC. 2003. North American weather-type frequency and teleconnection indices. International Journal of Climatology 23: 21 -45.

Sneyers R. 1990. On the Statistical Analysis of Series of Observations. WMO: No $; 143$.

Spellman G. 2000a. The application of an objective weather-typing system to the Iberian Peninsula. Weather 55: 375-385.

Spellman G. 2000b. The use of an index-based regression model for precipitation analysis on the Iberian Peninsula. Theoretical and Applied Climatology 66: 229-239.

Stefanicki G, Talkner P, Weber RO. 1998. Frequency changes of weather types in the Alpine region since 1945. Theoretical and Applied Climatology 60: 47-61.

Štìpánek P. 2004. AnClim - software for time series analysis (for Windows). Department of Geography, Faculty of Natural Sciences. Masaryk University: Brno; 1.47 MB.

Svensson C, Jakob D, Reed DW. 2002. Diurnal characteristics of heavy precipitation according to weather type at an upland site in Scotland. International Journal of Climatology 22: 569-585.

Szinell CS, Bussay A, Szentimrey T. 1998. Drought tendencies in Hungary. International Journal of Climatology 18: $1479-1491$.

Trenberth KE, Paolino DA. 1981. Characteristics patterns of variability of sea level pressure in the northern hemisphere. Monthly Weather Review 109: 1169-1189.

Trigo RM, DaCamara C. 2000. Circulation weather types and their influence on the precipitation regime in Portugal. International Journal of Climatology 20: 1559-1581.

Trigo RM, Palutikof JP. 2001. Precipitation scenarios over Iberia. A comparison between direct GCM output and different downscaling techniques. Journal of Climate 14: 4422-4446.

Trigo RM, Pozo-Vázquez D, Osborn TJ, Castro-Díez Y, Gámiz-Fortis S, Esteban-Parra MJ. 2004. North Atlantic oscillation influence on precipitation, river flow and water resources in the Iberian Peninsula. International Journal of Climatology 24: 925-944.

Ullbrich V, Christoph M, Pinto G, Corte-Real C. 1999. Dependence of winter precipitation over Portugal on NAO and baroclinic wave activity. International Journal of Climatology 19: 379-390.

Ventura F, Rossi P, Ardizzoni E. 2002. Temperature and precipitation trends in Bologna (Italy) from 1952 to 1999. Atmospheric Research 61: 203.214.

Vicente-Serrano SM, Cuadrat JM. 2002. Desarrollo de un método analítico para la obtención del SPI (Standardized Precipitation Index) como herramienta para el seguimiento y prevención de sequías climáticas. In La Información Climática Como Herramienta de Gestión Ambiental, Cuadrat JM, Vicente SM, y Saz MA (eds). Universidad de Zaragoza: Zaragoza; 145-153.

Vicente-Serrano SM, Saz MA, Cuadrat JM. 2003. Comparative analysis of interpolation methods in the middle Ebro valley (Spain): application to annual precipitation and temperature. Climate Research 24: 161-180. 
Vicente-Serrano SM. 2004. Evolución Espacio-temporal de las Sequías en el Sector Central del Valle del Ebro: Causas y Consecuencias Ambientales. Universidad de Zaragoza: Zaragoza; 1258.

Vicente-Serrano SM, Cuadrat JM, González-Hidalgo JC, Romo A. 2004a. Analysis of the temperature, precipitation and soil moisture influence on natural vegetation productivity in the middle Ebro valley (NE-Spain) using NOAA-AVHRR images. Ecology, Conservation and Management of Mediterranean Type Ecosystems of the World. Millpress ed: Rotterdam; 4.

Vicente-Serrano SM, González-Hidalgo JC, de Luis M, Raventós J. 2004b. Spatial and temporal patterns of droughts in the Mediterranean area: the Valencia region (East-Spain). Climate Research 26: 5-15.

Vicente-Serrano SM. 2006. Differences in spatial patterns of drought on different time scales: an analysis of the Iberian Peninsula. Water Resources Management 20: 37-60.

von Storch H, Zorita E, Cubasch V. 1993. Downscaling of global climate change estimates to regional scales: an application to Iberian rainfall in wintertime. Journal of Climate 6: 1161-1171.

Wallace JM, Gutzler DS. 1981. Teleconnections in the geopotential height field during the Northern Hemisphere winter. Monthly Weather Review 109: 784-812.

Wanner H, Rickli R, Salvisberg E, Schmutz C, Schüepp M. 1997. Global climate change and variability and its influence on Alpine climate. Theoretical and Applied Climatology 58: 221-243.

Wheeler D, Martín-Vide J. 1992. Rainfall characteristics of mainland Europe's southerly stations. International Journal of Climatology 12: $69-76$.

Wilby R. 1993. Evidence of ENSO in the synoptic climate of the British isles since 1880. Weather 48: 234-239.

Wilby RL, Wigley TML. 1997. Downscaling general circulation model output: a review of methods and limitations. Progress in Physical Geography 21: 530-548.

Wilby RL, Barnsley N, O’Hare G. 1995. Rainfall variability associated with Lamb weather types: the case for incorporating weather fronts. International Journal of Climatology 15: 1241-1252.

Wilby RL, Hassan H, Hanaki K. 1998. Statistical downscaling of hydrometeorological variables using general circulation model output. Journal of Hydrology 205: 1-19.

Yarnal B. 1993. Synoptic Climatology in Environmental Analysis. Belhaven Press: Londres; 195.

Yarnal B, Frakes B. 1997. Using synoptic climatology to define representative discharge events. International Journal of Climatology 17: 323-341.

Yarnal B, Comrie AC, Frakes B, Brown DP. 2001. Developments and prospects in synoptic climatology. International Journal of Climatology 21: 1923-1950. 